\title{
ODPOWIEDZI NA ANKIETĘ ANTROPOLOGICZNĄ „ETNOGRAFIA - ETNOLOGIA - ANTROPOLOGIA KULTUROWA DZISIAJ. CELE, ZAKRESY I PRAKTYKI BADAWCZE ORAZ WYZWANIA NA PRZYSZŁOŚĆ”
}

\author{
Zbigniew Jasiewicz \\ jasezb@amu.edu.pl \\ Instytut Etnologii i Antropologii Kulturowej \\ Uniwersytet im. Adama Mickiewicza w Poznaniu
}

Wartość tej ankiety polega na próbie dotarcia do sposobów myślenia o dyscyplinie przez jej przedstawicieli. Pośrednio dostarczy materiału dotyczącego jej obecnego stanu. Odpowiedzi na nią będą ważne dla refleksji nad sytuacją dyscypliny i zastanawiania się nad jej przyszłością; staną się ponadto dokumentem swego czasu. Ankieta obecna będzie cenna dla historii etnologii / antropologii kulturowej także dlatego, że nawiązując do podobnej sprzed 38 lat stworzy punkt odniesienia umożliwiający porównania. Wskaże na różnice zarówno w stanie umysłów etnologów / antropologów kulturowych, jak i w sytuacji dyscypliny w roku 1980, kiedy to Redakcja „Polskiej Sztuki Ludowej” rozesłała ankietę, jak i obecnie. Ujawni także problemy, które nadal są ważne i również dzisiaj są przedmiotem uwagi. Odpowiedzi na obie ankiety były i będą uwarunkowane czasem, w którym zostały przygotowane. Lata 1980 i 1981, kiedy ankieta „Polskiej Sztuki Ludowej” została rozesłana a jej wyniki opublikowane, to czas kryzysu nie tylko rzeczywistości Polskiej Rzeczpospolitej Ludowej, ale również wewnątrz dyscypliny. Część środowiska, szczególnie młode pokolenie etnografów / etnologów / antropologów kulturowych, żądało zmian i powrotu do szerokiego rozumienia dyscypliny, przerwanego w okresie socjalizmu, kiedy to schroniła się ona w bezpiecznej niszy studiów nad kulturą ludową, a także włączenia się do nurtu antropologii światowej. Dzisiaj, jak sądzę, nie mamy poczucia 
utraty przedmiotu badań i zagrożenia istnienia dyscypliny. Różnice w jej sytuacji i świadomości ją uprawiających ukazuje już sposób formułowania pytań w obu ankietach. Pytanie „Jakie wyzwania stawia przed dyscypliną przyszłość?” w obecnej ankiecie jest odmienne od pytania w ankiecie z roku 1980: „Jaka jest przyszłość etnografii?", które skierowane było nie na zadania dyscypliny, ale na jej los.

\section{Co to jest etnografia/etnologia/antropologia (jej miejsce wśród innych dyscyplin, cele, metody)?}

W pytaniu pojawia się nazwa trójczłonowa: etnografia/etnologia/antropologia. Twórcy ankiety pominęli ludoznawstwo wymienione w podsumowaniu poprzedniej ankiety. Pozostało ono w nazwie Polskiego Towarzystwa Ludoznawczego. Na ziemiach polskich nie nadano przymiotnika „ludoznawczy” żadnej z placówek naukowych w odróżnieniu od krajów niemieckojęzycznych, z ich uniwersyteckimi Seminar für Volkskunde i muzeami. Niewielu przedstawia się dziś jako ludoznawcy, są to zwykle pasjonaci, często regionaliści, niezwiązani z instytucjami naukowymi, zainteresowani kulturą ludową. Określenie to będzie od noszone i będzie odchodziło do historii, podobnie jak słowo 'lud' wiązane z przeszłością i uznane za nieprzystające do współczesnych wartości.

Zbitka trójczłonowa w pytaniu i innych tekstach jest wynikiem długiej historii, co najmniej od XVIII wieku: potrzeb rozwoju nauki, inwencji i emocji badaczy, uwarunkowań lokalnych, presji ideologiczno-politycznej. Ta zbitka jest jednocześnie faktem współczesnym. My, profesjonaliści, jesteśmy z nią oswojeni. We właściwy nam sposób tłumaczymy znaczenie poszczególnych jej członów. Każdy $\mathrm{z}$ nas, przedstawiając się, wybiera jeden z nich lub posługuje się kilkoma, nie tylko w trakcie długiego życia, jak w moim przypadku, ale także w krótkim czasie tworzącym teraźniejszość. Wielość nazw, z którą dajemy sobie radę, ale nie jesteśmy z niej zadowoleni, jest dla nas tylko kłopotliwa, bo niekiedy różnicuje środowisko, jest niezrozumiała dla otoczenia. Pyta się nas: „Kim w końcu jesteście?”. Wymogi komunikowania się ze społeczeństwem, ale także porządkowania własnej dyscypliny, skłaniają do posługiwania się jedną nazwą.

Termin 'etnografia' przestał być w zasadzie stosowany jako określający całą dyscyplinę, a nawet dyscyplinę pomocniczą czy subdyscyplinę etnologii i antropologii. Oznacza dzisiaj najczęściej metodę badania rzeczywistości społeczno-kulturowej, 
przejmowaną także przez inne dziedziny nauki. Prawoznawstwo np. gotowe jest posługiwać się metodą określaną jako 'etnografia prawa'. Termin ten pozostał natomiast w nazwie muzeów.

Zdecydowaliśmy o przyjęciu nazwy etnologia jako nazwy głównej dyscypliny. Ta nazwa nadana została Komitetowi Nauk Etnologicznych, ważnemu dla nas w strukturze korporacyjnej PAN, powołanemu w roku 1975 z inicjatywy prof. Józefa Burszty, poprzedzonemu jednak przez powstałą w roku 1972 Sekcję Etnograficzną Komitetu Nauk Socjologicznych PAN. Nazwę 'etnologia' przyjął także kierunek studiów na uniwersytetach, znalazła się ona ponadto w nazwach katedr i instytutów uniwersyteckich. Pierwsza była Katedra Etnologii i Antropologii Kulturowej Uniwersytetu Warszawskiego w roku 1984, po niej pojawiły się inne. Przyjęcie nazwy 'etnologia' było wy razem wierności tradycjom europejskim, dołączenie do niej 'antropologii kulturowej' oznaczało pragnienie uczestnictwa w nauce światowej, utożsamianej przede wszystkim z atrakcyjną antropologią amerykańską. Spójnik „i” łączący etnologię i antropologię w nazwach placówek uniwersyteckich, jednocześnie wskazujący na autonomię obu członów, został zamieniony ukośnikiem. Nazwa z ukośnikiem: 'etnologia / antropologia kulturowa' autorstwa prof. Czesława Robotyckiego, zaproponowana została w trakcie posiedzenia Komitetu Nauk Etnologicznych PAN w Cieszynie w roku 2005. Jest stosowana, gdyż nadaje obu członom nazwy charakter synonimów.

Część uprawiających antropologię, głównie ze środowiska socjologicznego, przyjęła, wzorem antropologii brytyjskiej, nazwę ‘antropologia społeczna'. Występuje ona nie tylko w piśmiennictwie polskim, ale także w nazwie sekcji Polskiego Towarzystwa Socjologicznego oraz w nazwach zakładów instytutów socjologicznych. Wyraźna jest bliskość obu antropologii i dlatego uzasadnione jest ich łączenie pod wspólną nazwą 'antropologii społeczno-kulturowej'. Odmienne jednak są studia antropologiczne nawiązujące do tradycji filozoficznych, literaturoznawczych i kulturoznawczych, mające inny, w porównaniu z antropologią kulturową i społeczną, przedmiot badań, odmienne metody i niektóre założenia teoretyczne. Uprawiane są często pod nazwą 'antropologii kultury'. Nie są one antynomią antropologii kulturowej i społecznej, a towarzyszą jej, poszerzając obszary badań i dostarczając pewnych nowych inspiracji teoretycznych.

Podwojona nazwa 'etnologia / antropologia kulturowa' nie jest jednak dobrym rozwiązaniem w komunikowaniu się wewnątrz środowiska naukowego i ze społe- 
czeństwem. Być może zostanie ograniczona w przyszłości do 'antropologii'. Etnologia, etymologicznie związana z greckim słowem ethnos, oznaczającym plemiona, ludy, narody, ale także zbiorowości, tłumy, rzesze połączone wspólnymi zwyczaja$\mathrm{mi}$ (w tradycji biblijnej przede wszystkim obce, pogańskie, nie żydowskie), jest tu słabszym członem. Narzuca węższy w porównaniu z antropologią zakres badań związanych ze sprawami etnicznymi i dostrzeganymi poprzez nie różnicami kulturowymi. Dystans, obcość w stosunku do wskazywanych zbiorowości i społeczności, przypisany etnosowi w greckojęzycznej Biblii, właściwy był również dawnym etnologom, zainteresowanym odległymi ludami i traktującymi także własny 'lud' jako odrębny i egzotyczny. Przezwyciężanie w naszych badaniach owego dystansu i zwrócenie się także ku swoim grupom i cechom wspólnym ludzkości, a nie tylko różnicom, może przemawiać na korzyść nazwy 'antropologia’ o szerszym zakresie. Nazwa ta musi być jednak wyposażona w odpowiedni przymiotnik czy przymiotniki ze względu na przynależność człowieka do wielu światów, nie tylko społeczeństwa i kultury, ale także natury i biologii.

Dość tych nadmiernie rozbudowanych uwag związanych z nazwami dyscypliny, ciągle zmuszającymi do wyjaśnień. Do zasadniczego pytania: „Co to jest etnografia / etnologia / antropologia kulturowa?” dodałbym dodatkowe: „Kim są etnografowie, etnologowie, antropologowie?". Wprowadzam to uzupełnienie dlatego, aby podkreślić w nauce rolę czynnika pozanaukowego, jakim jest między innymi charakter badacza, przede wszystkim światopogląd, ale także indywidualne zdolności i preferencje. Światopogląd zajmujących się nauką, nieobojętny nawet w naukach formalnych, jest tym bardziej ważny w naukach empirycznych, społecznych i humanistycznych. Może wpływać na nasze rozumienie celów dyscypliny, wybór przedmiotu i metody badań. Potrafimy lub wydaje się nam, że jesteśmy w stanie ten wpływ kontrolować. Prowadzone badania i ich wyniki niekiedy zwrotnie oddziałują na światopogląd badacza, zmieniając go.

Cel etnologii/antropologii jest taki sam, jak innych dyscyplin społecznych i humanistycznych, a mianowicie poznawanie rzeczywistości społeczno-kulturowej. Poznawanie nazywane bywa wyjaśnianiem, interpretacją lub mającym sens tylko w naukach społecznych i humanistycznych - rozumieniem. Wszystkie te mentalne czynności, bez względu na swoją nazwę, mają pomóc nam w nawiązaniu kontaktu z rzeczywistością i uczynieniu z niej przedmiotu naszych rozważań. Uzyskana 
wiedza o niej służy także do rozwiązywania, wspólnie z praktykami, trudnych spraw teraźniejszości.

Pominięty w pytaniu przedmiot, lub inaczej zakres badań dyscypliny, kształtuje jej charakter i stanowi o odbiorze społecznym. Jest jednocześnie zmienny, co pokazuje choćby historia polskiej powojennej etnologii/antropologii. Poszerzała ona swój zakres badań od kultury ludowej do współczesnych zjawisk społecznokulturowych, dostrzeżonych najpierw w badaniach kultury robotniczej, a zaraz potem na wsi Polski północno-zachodniej - zasiedlonej przez osadników poddanych presji społecznej i kulturowej związanej z migracją. Od kultury wiejskiej do kultury miasta; od zagadnień uznawanych za marginalne - przysłowiowa stała się praca doktorska na temat gry w palanta (która dla mnie, pozbawionego szkoły w okresie okupacji, spędzającego całe dni na ulicy małego miasta, była ważnym elementem życia) - po sprawy o wymiarze szerszym, podejmowane wraz z antropologizacją dyscypliny, takie jak globalizacja, wielokulturowość, kulturowe aspekty zróżnicowania ekonomicznego, kultura korporacji itd. Nie ma sensu ograniczanie przedmiotu dyscypliny do skończonej liczby zjawisk i zagadnień, każda granica będzie przekraczana wraz ze zmieniającym się światem. Nasze kompetencje i tradycje dyscy pliny każą nam jednak zajmować się przede wszystkim zachowaniami ludzi i ich wytworami o charakterze społecznym, tworzącymi systemy kulturowe z takimi ich cechami jak zmienność i kontynuacja.

Pytanie o metody w tym pytaniu zapewne dotyczy sposobów uzyskiwania materiałów w trakcie badań. Podobnie jak inni etnologowie/antropologowie uznaję badania terenowe nie tylko za postępowanie dostarczające cennych informacji, ale także za wyróżnik naszej dyscypliny. Ważny w nich jest badacz, obserwowani przezeń i odpytywani ludzie oraz „teren”, miejsce, w którym prowadzone są badania, pozostające w różnym stosunku tak do badacza, jak i jego rozmówców. Przyjmuję szerokie rozumienie terenu, który może być wszędzie, za wyjątkiem może pokoju w instytucji badacza i jego mieszkania, do których zaprosił lub zaprosili się ludzie, z którymi rozmawia dla celów badań. Zwykle skłonni jesteśmy nie myśleć o osobie badacza i koncentrować się jedynie na wywołanych przez niego źródłach. Zapominamy, jak ważne dla nich są jego cechy i sposób działania: prezentacja siebie i celów badań oraz umiejętność nawiązywania kontaktów i prowadzenia rozmowy. Minimalizujemy rolę badacza także wówczas, kiedy nie dostrzegamy jego oddziaływania na charakter uzyskanych przez niego materiałów. Najbardziej jest ono widoczne 
w opisie, w którym własnymi słowami przedstawia on wyniki obserwacji. Nieco mniej w zapisach wy powiedzi rozmówców czy recytowanych przez nich tekstów, które są jednakże wywołane pytaniami badacza, jeszcze mniej w wypisach - posługuje się tu derywatami czasownika „pisać”, korzystając z odnalezionych czy dostarczonych mu w terenie dokumentów. Wpływ badacza na charakter wytworzonych przez niego materiałów, ich subiektywny charakter, może zostać uznany za słabość tego rodzaju źródeł. Nie ma jednakże lepszego sposobu dotarcia do rzeczywistości społeczno-kulturowej jak kontakt z jej twórcami i uczestnikami. Badacz, dysponujący dobrym warsztatem i świadomy zasad etycznych, może dostarczyć materiału, który choć nadal pozostaje jego sposobem postrzegania rzeczywistości badanych, z rzeczywistością tą pozostaje w bliskim związku.

Charakter źródeł pozyskanych w terenie zobowiązuje do ich krytyki. Krytyka źródeł nie jest w etnologii/antropologii rozwinięta. Są trudne w sprawdzaniu ze względu na ich niepowtarzalność, wywołaną unikatowością osoby badacza i sytuacji badań. Etnolog/antropolog, również ja, posługuje się wieloma innymi, poza badaniami terenowymi, technikami pozyskiwania materiałów. Są nimi ankieta, a także różnego rodzaju kwerendy zasobów źródeł zastanych: literatury, archiwaliów, zbiorów muzealnych, konieczne nie tylko przy opracowywaniu materiałów z badań terenowych, ale również przy przygotowywaniu ich programu.

\section{Jakie miejsce zajmuje w etnografii / etnologii / antropolo- gii kulturowej problematyka badań nad przeszłością?}

Przeszłość pojawia się w kilku rodzajach naszych badań. Pierwszy z nich zajmuje się obecnymi w teraźniejszości śladami przeszłości oraz ich oceną i wykorzystaniem. Ślady te występują pod różnymi postaciami, zawsze są przez współczesność przetwarzane. Zachowane zostały albo tylko w pamięci, albo też nadal funkcjonują w społeczeństwie i kulturze, czasami, jeśli są źle oceniane, pod nazwą reliktów lub przeżytków. W oparciu o nie zbudowana została znaczna część etnograficznej wiedzy o kulturze ludowej, przedstawianej jako pełny system społeczno-kulturowy istniejący w przeszłości, tylko przez niektórych badaczy rozpoznawany jako szczególny rodzaj teraźniejszości - praesens ethnographicum. Przyjęcie tej wytworzonej przez etnografów wiedzy może skutkować pojawieniem się „pamięci etnograficznej” dostrzeganej wówczas, kiedy obrazy kultury z prac etnograficznych łączy się 
z pamięcią indywidualną i społeczną. Spotykamy się z nią w trakcie badań terenowych, kiedy otrzymujemy informacje ukształtowane przez dzieła etnograficzne, na przykład Oskara Kolberga, przekazywane z pełną wiarą jako pochodzące z pamięci własnej, indywidualnej lub podzielanej przez społeczność. Wiedza o kulturze ludowej (przymiotnik „ludowa” czyni z niej kulturę tradycyjną) jest zatem etnografią historyczną, uzupełnianą danymi dotyczącymi przetrwania i funkcjonowania elementów z przeszłości we współczesności badaczy. Do tego kierunku badań nawiązują studia nad tradycją, wykraczające poza zakres kultury ludowej, a także, tak ważne obecnie, studia nad dziedzictwem kulturowym.

To, co dziedziczymy z przeszłości, pozytywnie wartościowane, określane jest jako dorobek przeszłych pokoleń, najchętniej przodków, pomniki albo skarby przeszłości. Sięgamy po nie, przystosowujemy do współczesnego życia i użytkujemy jako współtworzące naszą wyróżniającą się tożsamość, zagrożoną globalizacją. Drugi kierunek stanowią badania, które przeszłość i teraźniejszość przedstawiają jako jeden nurt wydarzeń, w którym to, co było dawniej współtworzy współczesne życie społeczno-kulturowe i pozwala je wyjaśnić. Są to studia historyczno-etnograficzne, dzisiaj mniej już popularne, ale takimi było wiele prac na przykład prof. Józefa Burszty i także moja praca doktorska, opublikowana zresztą pod tytułem Studia historyczno-etnograficzne nad kowalstwem wiejskim w Wielkopolsce (1963). Wreszcie ostatni wyróżniony przeze mnie rodzaj studiów traktuje przeszłość jako byt autonomiczny, który staramy się poznać, stosując metody antropologiczne. W jego ramach źródła historyczne traktujemy jakby były naszymi rozmówcami i stawiamy im antropologiczne pytania. Znaczenie tego rodzaju badań potwierdza, tak bardzo zauważalna, antropologizacja historii uprawiana przez historyków.

Elementy wszystkich tych trzech rodzajów studiów występują w badaniach nad historią etnologii/antropologii. Za G.W. Stockingiem dostrzega się w nich nastawienie wynikające z przyjmowanych celów, określane jako historyzm i prezentyzm. W swoich studiach nad historią dyscypliny nazwałem siebie „prezentystą umiarkowanym". Dzisiaj wiem, że owo rozróżnienie, tak przydatne w analizie postaw badaczy, nie musi być obowiązujące w ich praktyce. W obecnych pracach nad źródłami wywołanymi i utrwalonymi przez Oskara Kolberga staram się być jednocześnie „prezentystą" $i$ „historystą".

Związek z przeszłością dawnej etnografii polskiej, mającej za swój przedmiot kulturę ludową, umożliwił zaliczenie jej do zespołu nauk historycznych, a nawet 
określanie jej jako nauki pomocniczej historii. Konsekwencją tego jest utrzymująca się przynależność większości Instytutów oraz Katedr Etnologii i Antropologii Kulturowej do Wydziałów Historycznych uniwersytetów oraz wspólne bytowanie etnologii z archeologią w ramach Instytutu Archeologii i Etnologii PAN. Etnologia / antropologia kulturowa nie jest nauką historyczną, jej głównym przedmiotem jest współczesność badacza, nie powinna jednakże rezygnować ze swoich kompetencji zajmowania się przeszłością. To one tworzą jedną z jej cech i stanowią o jej tożsamości.

\section{W jakim stopniu możemy współcześnie mówić o dominujących stylach praktykowania antropologii; czy można by wskazać nurty i orientacje badawcze o charakterze paradygmatycznym?}

Podzielam stwierdzenie autorów ankiety. We współczesnej etnologii / antropologii kulturowej zapanował pluralizm teoretyczny, właściwy zresztą także innym dyscyplinom społecznym i humanistycznym. Minął czas fascynacji strukturalizmem, a nieco później antropologią symboliczną lub interpretatywną, antropologią kognitywną, inaczej etnonauką, rodzimą (dla mnie podwójnie, bo poznańską), społeczno-regulacyjną teorią kultury, a także dwugeneracyjną 'nową polską etnologią', zresztą niedysponującą zwartym systemem teoretycznym i będącą raczej ruchem społecznym etnologów. Każda z tych szkół czy kierunków była wyposażona w teksty kanoniczne i posiadała swoich mistrzów czy liderów. W okresach ich popularności na gruncie polskim zaobserwować można było zaciskanie gorsetu schematów teoretycznych przy pomocy niezliczonej ilości powołań w artykułach na pisma klasyków kierunku, dorównującej wymogom cy towania z okresu dominacji marksizmu, czasów mojej młodości. Warto zastanowić się, czy skłonność do dogmatycznego i ekskluzywnego traktowania pojawiających się nowych kierunków teoretycznych w etnologii polskiej była uwarunkowana atmosferą zmagań z tradycyjną etnografią, czy też, choćby w pewnym stopniu, przejętą z systemu totalitarnego potrzebą wspierania się monolityczną konstrukcją myślową i stojącym za nią autorytetem osobowym. Celem wielu prac z tego okresu stawało się nie rozwiązanie problemu znajdowanego w rzeczywistości społeczno-kulturowej, ale uzasadnienie tez teoretycznych i oddanie hołdu ich twórcy. Czas podobnego postępowania minął, było ono jednak chyba nieuniknione, a jego następstwa w pewien sposób pożyteczne. 
Zwróciło ono uwagę na znaczenie teorii. Bez właściwego teorii formułowania pytań o istotę świata i zasady jego wyjaśniania nie byłby możliwy nie tylko rozwój, ale także istnienie nauki. Jestem jednak zwolennikiem instrumentalnego, a nie esencjonalnego traktowania teorii i w swojej praktyce badawczej przyjmowałem założenia odpowiadające, zgodnie z moimi przekonaniami, podejmowanej problematyce i przyjmowanym celom. Starałem się i staram sprawdzać tezy teoretyczne w materiale empirycznym, a nie kształtować przy ich pomocy obraz rzeczywistości. Pomaga mi w tym przekonanie o względności hermetycznych modeli teoretycznych, choć wiem, że są pożyteczne jako kategorie analityczne i przydatne, kiedy są krytycznie stosowane. W moim stosunku do teorii pewną rolę odgrywa także przeświadczenie o kumulatywnym w zasadzie charakterze rozwoju nauki, dysponującym na każdym jego etapie wieloma przejętymi z przeszłości twierdzeniami o naturze rzeczywistości społeczno-kulturowej, w każdorazowej teraźniejszości weryfikowanymi i uzupełnianymi o twierdzenia nowe.

\section{Jakie wyzwania stawia przed dyscypliną przyszłość?}

Zakładając w miarę stabilną sytuację Polski w jej otoczeniu i kontynuację kierunku przemian ekonomicznych i społecznych oraz dynamikę właściwą nauce, można przewidywać wystąpienie wyzwań, które dzielą się na płynące ze świata zewnętrznego wobec nauki oraz te powstające wewnątrz dyscypliny, o charakterze poznawczym, organizacyjnym i etycznym. Ważnym wyzwaniem zewnętrznym są przede wszystkim potrzeby rozwiązywania istotnych społecznie problemów, pozostających w kompetencjach etnologii / antropologii kulturowej. Należą do nich między innymi różnice w przyjmowanych przez społeczeństwo wartościach, ujawniające się na przykład w postawach wobec świata zewnętrznego i pochodzących z tego świata obcych, nierówności w pozycji ekonomicznej i wyposażeniu kulturowym oraz potencjalnych konflików na tym tle; mechanizmy funkcjonowania pomnażającego kapitał społeczny społeczeństwa obywatelskiego, rosnące zainteresowanie własnym dziedzictwem kulturowym społeczności lokalnych, regionalnych i społeczeństwa narodowego, przeciwstawiających się globalizacji; konieczność rozpoznania przez społeczeństwo narodowe świata, z którym kontakty niosą zarówno korzyści, jak i zagrożenia. Są to także wymagania rynku pracy i związana z nim racjonalizacja przez młodych ludzi wyboru kierunku studiów. Wiele odpowiedzi dyscypliny 
nie będzie oczywistych zarówno ze względu na skomplikowanie rzeczywistości, ze zróżnicowanymi odbiorcami proponowanych przez naukę analiz i propozycji działań, jak i niejednorodne światopoglądowo i w zakresie metodologii środowisko naukowców. Dylemat czy etnolog/antropolog ma być rzecznikiem zmian wiązanych z wyobrażoną przyszłością, czy obrońcą wartości łączonych z wyidealizowaną przeszłością jest rozwiązywany indywidualnie. Podejmujący wybór winien jednakże być świadomy następstwa swoich działań, które zsumowane z działaniami innych mogą prowadzić albo do nadmiernej dezorganizacji systemu społeczno-kulturowego, albo też do jego stagnacji. Odpowiedź etnologii/antropologii kulturowej powinna obejmować stworzenie katalogu spraw uznanych za ważne społecznie, potraktowanie ich za warte kontynuacji, jeśli badania nad nimi były już prowadzone lub poszerzenie o nie przedmiotu badań. Sprawy te zostały wymienione powyżej, dodam tylko te związane z profilem wykształcenia studentów etnologii oraz wymogami kontaktowania się przedstawicieli dyscypliny ze społeczeństwem. Studentów, których zapewne będzie mniejsza liczba niż obecnie, trzeba nie tylko kształcić na najwyższym poziomie w zakresie poznawania rzeczywistości, ale także przygotować do podejmowania badań nad problemami istotnymi lokalnie i ponadlokalnie oraz ich prezentowania społeczeństwu. Dyscyplina, po to, aby być rozpoznawalna i dla dobrego kontaktowania się z otoczeniem, winna dążyć do przyjęcia jednolitej, najlepiej jednoczłonowej nazwy i umocnienia swoich reprezentacji, którymi są towarzystwa i komitety naukowe.

Wyzwania zależne od zewnętrznych determinant funkcjonowania nauki nie są izolowane od wyzwań wywołanych potrzebami dyscypliny. Są nimi przede wszystkim potrzeby poznawcze rozwijania metod opisu i związanej z nim dokumentacji, wyjaśniania i tworzenia twierdzeń dotyczących badanej rzeczywistości. Dlatego w etnologii / antropologii kulturowej nadal stosowana i dostosowywana do zmieniającego się przedmiotu badań będzie metoda badań terenowych, tak bardzo ważna dla uzyskania materiałów do studiów jakościowych. Konieczny w niej kontakt osobisty poszerzony zostanie zapewne, już to się zresztą dzieje, o możliwości porozumiewania się z badanymi osobami przy pomocy środków elektronicznych. Utrzymane zostanie i rozwinięte podmiotowe traktowanie rozmówców, nie przyjmie się jednak absurdalna teza, pojawiająca się niekiedy, że to nasi informatorzy są podmiotami badań. Nadal obecny będzie pluralizm teoretyczny rozumiany jednakże nie jako etap o znamionach kryzysu, przejścia z jednego paradygmatu do innego, 
lecz jako stan trwały. Praktykowana, a nie deklarowana, współpraca międzynarodowa może osłabić podział na centra i peryferie naukowe lub wprowadzić ich rotację, przy ujawnianiu zasobów materiałowych i koncepcji teoretycznych ośrodków dotąd niedostrzeganych. Poszerzona zostanie świadomość badaczy na temat ich własnych uwarunkowań społeczno-kulturowych i psychicznych. Bardziej powszechne będzie łączenie przez nas wiedzy teoretycznej z umiejętnościami gromadzenia i opracowywania materiału. Indywidualne predyspozycje są jednak różne i nadal część spośród nas będzie specjalizować się w zakresie teorii i metod, oby jednak bez odrywania się od warsztatu badawczego i przedmiotu dyscypliny.

Uznanie etnologii / antropologii kulturowej jako dyscypliny o granicach „miękkich", przenikalnych, nie powinno osłabiać starań o zachowanie, być może, już nie jej odrębności, a autonomii. Służyć temu mogą m.in. podręczniki, których brakuje oraz studia nad jej historią. Struktury organizacyjne dyscypliny, tak ważne dla utrzymania więzi oraz w kontaktach z otoczeniem, czynnik pozapoznawczy, przydatne być powinny w tworzeniu lepszych warunków badań i porozumiewania się $\mathrm{w}$ środowisku zajmujących się dyscypliną, a nie być celem samym dla siebie.

Przyszły kształt dyscypliny będzie wypadkową warunków, w których przyjdzie jej działać oraz jej potencjału, którego najważniejszym dobrem są etnologowie/antropologowie $\mathrm{z}$ ich umiejętnościami poznawczymi i organizacyjnymi oraz wrażliwością społeczną.

\section{Janusz Barański}

j.baranski@iphils.uj.edu.pl

Instytut Etnologii i Antropologii Kulturowej

Uniwersytet Jagielloński

W wypowiedzi poniższej ${ }^{1}$ przyjmuję nieco „zachowawczy” punkt widzenia, idąc w ślad za bodaj najbardziej rozpowszechnionym rozumieniem zakresu nauk etnologicznych (etnologii, antropologii kulturowej, antropologii społecznej, ludoznawstwa, Volkskunde, Vólkerkunde itp.), a mianowicie kultury rozumianej jako sposób życia ludzi. Wprawdzie niektórzy z uprawiających owe nauki, na przykład reprezentanci antro-

\footnotetext{
${ }^{1}$ Wypowiedź jest nieco zmienioną i skróconą wersją Wstępu do mojej książki, pt. Etnologia w erze postludowej, która ma się ukazać niebawem.
} 
pologii społecznej, być może nie zgodziliby się z tym rozumieniem zakresu dyscypliny, argumentując, że jest ona czymś w rodzaju socjologii porównawczej, a więc zainteresowana społeczną kondycją człowieka. Uważam jednak, że podtrzymywanie szerokiego rozumienia kultury (kultur), jako atrybutu człowieka, jest najlepszym warunkiem sine qua non uprawiania dyscypliny, służącym zarazem utrzymaniu jej odrębności w obrębie humanistyki i nauk społecznych.

Wiele już napisano o owych sposobach życia (ways of life), począwszy od zgoła pionierskiej Sumnerowskiej koncepcji folkways: „Sposoby spełniania spraw potocznych $\mathrm{w}$ danym społeczeństwie tak, aby zaspokoić ludzkie potrzeby i pragnienia wraz z wierzeniami, pojęciami, kodami i standardami dobrego życia, które wpływają na te sposoby, będąc z nimi w genetycznym związku" (Sumner 1906: 59; cyt. za: Staszczak 1987: 133). Pluralis terminu wskazuje na wielość owych sposobów, rozumianych ponadto, jak widać, w kategoriach niesformalizowanej struktury. Tak zgoła archetypicznie rozumiane pojęcie kultury nie straciło na aktualności do dziś i można je aplikować do sposobów życia wyodrębniających się lub wyodrębnianych wedle kryteriów: narodowego, etnicznego, regionalnego, lecz także miejskiego, wiejskiego, klasowego, genderowego, stylowego, subkulturowego, nowoplemiennego, politycznego, religijnego, artystycznego czy - nomen omen - popularnego. Łaciński populus oznacza między innymi lud, nie powinno zatem dziwić łączenie go na przykład z kulturą popularną przez takich uznanych badaczy jak Pierre Bourdieu (2005) czy John Fiske (2010).

Osobiście nie mam wątpliwości co do naczelnej pozycji tej dyscypliny wśród nauk o człowieku - w sposób najbardziej ogólny, ambitny i fundamentalny rozumie pole swych badań, czego pośrednim dowodem są inspiracje, które pełnymi garściami czerpią z niej, zwłaszcza w ostatnich czasach, dyscypliny sąsiednie: od socjologii do literaturoznawstwa. W tym rozumieniu blisko jej nade wszystko do filozofii i to nie tylko z powodu wspomnianej rozległości zakresowej. Powiada się czasem o tej ostatniej, pierwszej historycznie i logicznie metodycznej emanacji umiłowania mądrości, że jest konceptualizacją doświadczenia potocznego. Innymi słowy filozofowanie to proces skrępowanego jedynie rygorami ratio porządkowania treści poznawczych, będących wynikiem codziennego nieskrępowanego oglądu rzeczywistości. W tym rozumieniu potencjalnie każdy, kto ma władzę zmysłowego i umysłowego postrzegania tego, co dzieje się wokół niego i w nim, może być filozofem, co było wszak udziałem jej greckich twórców przed wiekami. Dziś rzecz 
wygląda nieco inaczej, pozostaje jednak podstawowa zasada - filozof nie posługuje się metodami i technikami nauk empirycznych: nie ślęczy w laboratoriach, nie wierci dziur w ziemi, skale czy w ludzkich wnętrznościach, nie rozdaje ludziom ankiet do wypełnienia. Oczywiście posiłkuje się często ustaleniami nauk, które do powyższych czynności sięgają, lecz nade wszystko formułuje twierdzenia ogólne, które - jak utrzy mywała szkoła pozytywizmu logicznego - mają walor metafizyczny, są heurystycznym „rusztowaniem" systemu ontologii, epistemologii czy nawet aksjologii, które zwrotnie bywają wszak z kolei inspiracją dla nauk szczegółowych.

Otóż filozofię i etnologię, najbliższą tej pierwszej ze względu na zakres i formę metodycznej refleksji, łączy nie tylko owa rozległość zakresowa, lecz również jej treść - potoczność, codzienność, zwyczajność, którą filozof i etnolog doprowadzają wszakże na dalszych etapach dociekań do postaci ogólnych: ontologii i etnosów, epistemologii i racjonalności, aksjologii i systemów wierzeń itd. To na ową potoczność i codzienność, jako punkt wyjścia drogi badawczej, wskazuje zarówno Heideggerowskie „bycie”, określające - według filozofa z Fryburga - początek wszelkiego filozofowania, jak również antropologiczna kategoria „sposobów życia” ludzi, wyrażająca zakres przedmiotowy nauk etnologicznych. Ta analogia eksponuje zarazem pierwszeństwo - by użyć znanych uniwersaliów filozoficznych - egzystencji nad esencją, owych „być” i „żyć", które określają niezliczone modusy życiowych jednostkowych i zbiorowych dróg, którymi zmierzają ludzie. By owe drogi, sposoby życia ludzi, podległe zresztą nieustannej zmienności, należycie poznać, etnolog zmuszony jest do permanentnej obecności w badanej rzeczywistości, intensywnej z nią interakcji, podobnie jak i filozof. Tylko ten drugi praktykuje to niejako w sposób naturalny przyglądając się otaczającej go rzeczywistości. Etnolog czyni to samo, choć często dotyczy to świata innego, niż jego własny. Wszelako nie musi to być kraina znajdująca się na antypodach, gdyż może to być nawet świat subkultury, nowoplemienia czy sceny muzycznej w obrębie tego samego etnosu, w którym funkcjonuje zarówno badacz, jak i badani. Może on jednak okazać się ontologicznie równie odległy od świata badacza, jak rozmaite egzotyczne rubieże. To wszakże ujawnia się dopiero w świetle etnograficznych badań terenowych, polegających - najogólniej mówiąc na bliskiej, czasem wręcz intymnej, relacji z badanymi.

To szczególne narzędzie metodologiczne, które czyni z etnologii rodzaj empirycznej filozofii (zob. Howell 2013: 153), prowadzi do odkrycia samych pierwocin czyjejś codziennej wiedzy, obyczajów, form i treści praktykowanej twórczości, wyobrażeń 
o sobie i innych, jak również otaczającym świecie przyrody, a nawet odległych przestrzeniach kosmosu. Tutaj dokonuje się rekonstrukcja implicit philosophy, jak zwykł mawiać Clyde Kluckhohn, a co przed nim Husserl określał mianem Lebenswelt, po nim zaś Clifford Geertz jako tacit knowledge, którą każdy zwykł posiadać i uprawiać w różnym stopniu, choć dzieje się to zwykle w trybie praktyki kulturowej. Tak rozumiana filozofia codzienna, zwyczajność składa się na sposób życia, co ostatecznie można sprowadzić do eksploatowanego przez etnologów pojęcia kultury.

O ile jednak filozof, przypomnijmy, zaczynając od własnego potocznego doświadczenia, wznosi następnie „rusztowanie” konceptualizacji w procesie kontemplacji i/lub debaty odbywającej się w zaciszu gabinetu lub, jak dawniej, podczas spacerów w gaju oliwnym, to etnolog za materiał bierze potoczne doświadczenia innych, co Michael Herzfeld określa jako „porównawcze badanie zdrowego rozsądku” (2004: 9), a intelektualna praca etnologa ma nade wszystko charakter zstępujący - polega na odkrywaniu niejako geologii owych doświadczeń i to z użyciem metod i technik nauk empirycznych. Zwykle nie odbywa się to jednak w gabinecie (choć, jak wiadomo, zawsze byli i są badacze gabinetowi), lecz w tak zwanym terenie, którym może być i ów gaj oliwny. Nie oznacza to wszak porzucenia ambicji teoretycznych, których realizacja wymaga badań porównawczych, jak chce Herzfeld - budowania modeli światów kulturowych i ich wewnętrznych morfologii, przepływów między nimi i ich wewnętrznej dynamiki itd. To jednak realizowane jest nade wszystko z udziałem materiału pozyskanego $\mathrm{w}$ trakcie wspomnianych badań terenowych, $\mathrm{z}$ użyciem narzędzi podlegających drobiazgowym regułom metodologii badań empirycznych, czego nie można powiedzieć o sposobach tworzenia systemów filozoficznych.

W tym ujęciu potoczność, zwyczajność określają pojęcia zakresowo bliskie kulturze rozumianej jako sposób życia, na którą składają się idee, wartości, praktyki prymarne, powszednie, codzienne, choć również i te niepowszednie - typowe dla czasu szczególnego: święta, narodzin, śmierci, aktywności twórczej. Znajdziemy je wszędzie: na wsi i w mieście, wśród lewicowców i prawicowców, subkulturowców i sekciarzy, w protokole dyplomatycznym i obyczaju codziennym, w świątyni i klubie nocnym, wśród młodych i starych, bogatych i biednych, ludzi pracy fizycznej i intelektualistów. Dziedziny życia składające się na tę codzienność, interesujące dla oglądu antropologicznego -źródłowego, skupionego na pierwotnych formach zakorzenienia w rzeczywistości, autorytecie, wspólnocie, aksjologii, wierze religijnej czy politycznej, nieformalnej sytuacyjnej logice - to raczej obyczaj (zwyczaj) niż prawo, folklor 
(estetyka codzienna) niż sztuka, kultura lokalna (regionalna) niż narodowa, tradycja niż historia, stosunki sąsiedzkie niż społeczeństwo, wspólnota niż państwo.

To te i podobne zjawiska, raczej skali mikro, niesformalizowane i oddolne, przebiegające w poprzek sformalizowanych taksonomii społecznych, prawnych, aksjologicznych itd., pierwotna - by tak rzec - materia sposobów życia, zmusza do praktykowania oglądu badawczego niejako oddolnie (warm's-eye view), co dobrze oddaje znana dyrektywa usilnej pracy nad uchwyceniem „tubylczego punktu widzenia”. Perspektywa ta wyznacza zarazem teoretyczny zrąb pola zainteresowań nauk etnologicznych oraz podsuwa dalsze możliwe tereny eksploracji z wykorzystaniem modyfikowanych podejść do zjawisk dawniejszych; Alfred Gell (1998) równie sprawnie i przekonująco przeprowadzał analizy sztuki Trobriandczyków, co ready mades Duchampa z użyciem stworzonej przez siebie kategorii techniki zaczarowania - technology of enchantment.

Tak tedy ustalenia na temat dawniejszej tradycji mogą być przydatne w rozumieniu współczesnego tradycjonalizmu i dziedzictwa, zaś na temat folkloru - folkloryzmu czy folku; dalej, dawniejsze układy plemienne znajdują zmodyfikowaną kontynuację we współczesnych nowoplemionach; ustalenia na temat kultury zawodowej okazują się przydatne w rozumieniu kultur organizacyjnych; mechanizmy magii znaleźć można dziś w świecie polityki czy reklamy; nomadyzm znany z historycznych przekazów przyjmuje obecnie formę rozmaitych diaspor czy peregrynacji gastarbeiterów; zinstytucjonalizowany i sformalizowany rytuał przejawia się w formie rozproszonej rytualności i performatywności - w mediach, w życiu społecznym, w sztuce, w turystyce. Struktury mityczne znajdziemy dziś w polityce, literaturze, kulturze popularnej i w zbiorowej wyobraźni; dawniejsze wzory kulturowe określające zakres etnosu znajdują obecnie wyraz w stylach życia przekraczających granice etniczne; obyczaj występuje pod postacią mody; technika na dobre zadomowiła się w przestrzeni kosmologicznej. Wreszcie ustalenia na temat grup lokalnych mogą się przyczynić do rozwoju wiedzy o współczesnym prymordializmie lub glokalizmie, choć i zjawiska skali globalnej są dziś przedmiotem zainteresowania antropologicznego, jak choćby Arjuna Appaduraia (2005) czy Tomasa Hyllanda Eriksena (2013), podobnie jak i poszukiwanie uniwersaliów kulturowych, czego przecież nie zaniechano.

Wiek XX w antropologii pozostawał pod znakiem wielkich teorii z jednej strony, z drugiej zaś, drobiazgowej aktywności empirycznej. Dziś wskazuje się na szczególny stan antropologii współczesnej - between-betweex - pomiędzy teorią a prak- 
tyką, ogólnym a szczegółowym, globalnym a lokalnym, diachronią a synchronią, akademicką pracą analityczną a codziennym zaangażowaniem. Nikt przy tym nie przykłada szczególnej wagi zarówno do wznoszenia gmachów owych wielkich teorii, jak i prowadzenia stacjonarnych i totalnych badań terenowych; Bruce Knauft mówi w tym przypadku wręcz o erze post-paradygmatycznej (2006: 425). Bo i zanikają też rozróżnienia na to, co ogólne i to, co szczegółowe, rozmywają się w ślad za niknącymi dawniejszymi społecznościami lokalnymi, ich izolacją geograficzną, tradycjonalizmem, poddaniem autorytetowi kultury, która $\mathrm{z}$ kolei rozumiana była w kategoriach księgi. Analogicznie zmniejsza się rola społeczeństw i państw narodowych, postępuje proces globalizacji, który z drugiej strony, sprzyja powstawaniu rozmaitych glokalizmów lub też globalnych sieciowych wspólnot, które tym bardziej nie pozwalają zapomnieć o tych dawniejszych, zagubionych w nieprzebytych puszczach czy górskich ostępach. Historia kulturowa toczy się - można by rzec spiralnie, a badacz wciąż obcuje zarówno z przeszłością, jak i współczesnością. Lecz multiplikuje się jego teren $\mathrm{i}$ - by tak rzec - eksploduje, zmuszając badacza do bycia nieomal w różnych miejscach naraz (multisited ethnography, Marcus 2008). Samoańczyków, inaczej niż w czasach Margaret Mead, trzeba dziś badać na Samoa i w Nowej Zelandii, i w USA; podobnie i współczesnych Podhalan - w Zakopanem, Bukowinie Tatrzańskiej i Chicago.

W polskim systemie nauki dawniejszy, historycznie nacechowany paradygmat uprawiania etnologii oznacza również instytucjonalne jej przypisanie naukom historycznym, stąd jej jednostki znajdują się na wydziałach historycznych właśnie. Tymczasem zakresy, teorie, metody rodzimej etnologii poszerzają się o podejścia z porządku nauk społecznych, co jest oczywistą konsekwencją przesuwania się uwagi na zjawiska będące przedmiotem zainteresowania anthropology at home. W konsekwencji rośnie rozziew między wyobrażeniami o etnologii, a tym, czym ona w istocie jest, rozziew, którego ofiarą padają nawet sami koledzy akademicy zasiadający w radach wydziałów oraz - co gorsza - decydujący o misjach, strategiach, planach, finansach, doktoratach i habilitacjach. Zdarzało się już, że elementarne niedostatki w znajomości dyscypliny - jej zakresu, teorii i metody - były przyczyną nie tylko kłopotliwych nieporozumień (np. konsternacja i niedowierzanie wywołane w mojej rodzimej radzie wydziału na wieść o doktoracie z etnologii na temat muzyki metalowej), lecz nawet dyskwalifikacji rozprawy, której autor przypadkiem hołdował 
idei na przykład surrealizmu etnograficznego, czemuś niepojętemu dla większości historyków o - nazwijmy to - wrażliwości pozytywistycznej.

Powyższe uwagi wyszły od źródeł i do nich też zmierzają. Ulf Hannerz (2013) w wydanej niedawno rozliczeniowej pracy na temat sytuacji antropologii stwierdza trzeźwo, że powinna ona pozbyć się wreszcie egzotycznej i antykwarycznej optyki i pracować nad wyrazistym wizerunkiem wyrażającym to, co antropolodzy zawsze robili: badania ludzkiego zróżnicowania. Dodajmy zatem: zróżnicowania bez granic (muzyka metalowa nie może tu być wyjątkiem, lecz regułą) - nie limitowanego geograficznie, klasowo czy społecznie, jak to miało miejsce w przypadku rodzimego zakresu wyznaczanego głównie przez dawniejszą kulturę ludową. Wszelako w polskiej tradycji badawczej modelowo ujęta ludowość, rozumiana w kategoriach pierwotności kulturowej, wciąż może być jednym z dyscyplinowych paradygmatów heurystycznych (wprawdzie wymagająca krytyki i modyfikacji), służących rozpoznawaniu rozmaitych światów kulturowych (nie wyłączając rzeczywistości wirtualnej), uchwyconych $\mathrm{w}$ akcie antropologicznej redukcji tematycznej w ich niesformalizowanej, oddolnej postaci. Kategoria ta tyleż wymaga przezwyciężenia, co - być może - płodnego rozwinięcia w duchu wspomnianych folkways. A może po prostu - ways?

\section{Bibliografia}

Appadurai, A. (2005). Nowoczesność bez granic. Kulturowe wymiary globalizacji (przeł. Z. Pucek). Kraków: Universitas.

Bourdieu, P. (2005). Dystynkcja. Społeczna krytyka władzy sądzenia (przeł. P. Biłos). Warszawa: Wydawnictwo Naukowe SCHOLAR.

Eriksen, T.H. (2013). Etniczność i nacjonalizm. Ujęcie antropologiczne (przeł. B. Gutowska-Nowak). Kraków: Wydawnictwo UJ.

Fiske, J. (2010). Zrozumieć kulturę popularną (przeł. K. Sawicka). Kraków: Wydawnictwo Uniwersytetu Jagiellońskiego.

Gell, A. (1998). Art and Agency. An Anthropological Theory. Oxford: Clarendon Press.

Hannerz, U. (2013). Diversity is Our Business, W: H. Jebens, K-H. Kohl (red.), The End of Anthropology (ss. 177-202). Wantage: Sean Kingston Publishing.

Herzfeld, M. (2004). Antropologia. Praktykowanie teorii w kulturze i społeczeństwie (przeł. M. M. Piechaczek). Kraków: Wydawnictwo Uniwersytetu Jagiellońskiego. 
Howell, S. (2013). Whatever Happened to the Spirit of Adventure, W: H. Jebens, K.-H. Kohl (red.), The End of Anthropology? (ss. 139-54). Canon Pyon: Sean Kingston Publishing.

Knauft, B.M.(2006). Anthropology in the Middle. Anthropological Theory 6 (4), 407-430.

Marcus, G. (2008). The End(s) of Ethnography: Social/Cultural Anthropology's Signature

Form of Producing Knowledge in Transition. Cultural Anthropology 1, 1-14.

Staszczak, Z. (red.). (1987). Słownik etnologiczny: terminy ogólne. Warszawa-Poznań: PWN.

Sumner, W.G. (1906). Folkways: A Study of the Sociological Importance of Usages,

Manners, Customs, Mores and Morals. Boston: Ginn and Company.

\section{Wojciech Józef Burszta}

wburszta@swps.edu.pl

Katedra Kulturoznawstwa SWSP

Uniwersytet Humanistycznospołeczny

\section{Co to jest etnografia/etnologia/antropologia (jej miej- sce wśród innych dyscyplin, cele, metody)?}

Zgadzam się w pełni z Michelem-Rolphem Trouillot, że w mocy pozostaje definicja antropologii społeczno-kulturowej jako otwartego zbioru praktyk i teorii, które podpadają pod starą formułę, iż anthropology is what anthropologists do (2003: 8). Istnieją formalne definicje, uporządkowania, podziały i dyscyplinarne wymogi, które funkcjonują po to, aby nasza nauka mogła być wpisania w schemat kompetencyjny dzisiejszej humanistyki. W neoliberalnym świecie tym bardziej trzeba uzasadniać sensowność, funkcjonalność i użyteczność wiedzy, którą się uprawia - po to są definicje i stojąca za nimi ideologia podziału terytorium poznawczego jako łupu dla poszczególnych nauk szczegółowych. Za tą formalną fasadą „tutaj my, tam wy” zaczyna się jednak to, co najciekawsze, a więc owo what anthropologists do. Nie sposób tego ująć w jakąkolwiek zwartą charakterystykę.

Terytorium działań antropologicznych rozciąga się zatem od wąskiego empiryzmu w starym stylu do panoramicznych ujęć filozoficznych; od zainteresowania konkretem w bardzo ściśle określonym społecznym mielieu - do fascynacji globalizacją. Dochodzą kolejne mody - neuroantropologia, transhumanizm, netnografia 
itp. Podobnie jak w innych naukach - podążamy tam, gdzie są pieniądze, to też wyznacza puls współczesności, ale przecież zawsze tak było (Geertz nie pojechał sobie, ot tak, na lata do Indonezji, ale był trybikiem w szerokim zamierzeniu badawczo-ideologicznym badań nad postkolonializmem). Słowem, każdy wpisuje się w rozumienie sensu antropologii poprzez to, co robi, czym się fascynuje i gdzie szuka inspiracji oraz sprzy mierzeńców.

\section{Jakie miejsce zajmuje w etnografii / etnologii / antropolo- gii kulturowej problematyka badań nad przeszłością?}

Od pewnego czasu nurt, nazwijmy go, „wiwisekcyjnym”, zyskuje na znaczeniu. Wiąże się to z pogłębiającą się tendencją do krytycznego mierzenia się zarówno z historią samej antropologii, jak i historią świata widzianą przez pryzmat kolonializmu, którego antropologia - chcąc tego, czy nie - była elementem. Co więcej, odpominanie przeszłości nie tylko ma moc wyzwalającą, ale pozwala zrozumieć, dlaczego antropologia nigdy nie była niewinną, bezinteresowną i apolityczną wiedzą, uprawianą - jak mawiał ironicznie Kurt Vonnegut - przez grono wrażliwych pań i panów. To ważne dla dzisiejszej samoświadomości także i dlatego, że wyznacza inną trajektorię opisu historii kultury jako praktykowania kapitalizmu w ramach promowania kultury euroatlantyckiej. Pozwala także lepiej zrozumieć badania postkolonialne i to wszystko, co dzieje się dzisiaj w ramach eksportu ideologii neoliberalnej na peryferie. Jeśli przeczyta się monumentalną pracę Jürgena Osterhammela Historia XIX wieku. Przeobrażenie świata (2013), można sobie uświadomić, jak wąską perspektywę proponowały tradycyjne wprowadzenia do dziejów naszej dyscy pliny, jak wiele w nich luk i białych plam. Dzisiaj, przede wszystkim dzięki reportażom historycznym, poszerza się kontekst rozumienia antropologii. Po lekturze książki Kongo. Opowieść o zrujnowanym kraju Davida Van Reybroucka (2016) nic już nie jest oczywiste, jak lubił mawiać Czesław Robotycki.

W kontekście krajowym owo odpominanie przeszłości wiąże się z ponownym zainteresowaniem (a właściwie z całkowitą zmianą optyki), jeśli chodzi o dzieje polskiego ludoznawstwa. Opowieść o narodzinach i dojrzewaniu polskiej etnografii abstrahowała dotąd od kwestii chłopskiego poddaństwa i zniewolenia. Obecnie objawia się ono w świetle teorii - no właśnie - postkolonialnych, chociaż baza źródłowa do tego istnieje od dziesięcioleci w ramach archiwum wiedzy z historii gospodarczej. Hi- 
storię polskiej etnografii trzeba w pewnym sensie napisać od nowa, uwzględniwszy to wszystko, co z niej było dotąd wypieranie w ramach - by znów odwołać się do nieodżałowanej pamięci M.R. Trouillot - uciszania pewnych aspektów przeszłości (niewolnictwo) kosztem uwypuklania wątków innych (chłopi jako „przechowalnik” rdzennej kultury). Nie do przecenienia w tym nurcie jest niesamowita powieść Stanisława Aleksandra Nowaka Galicyanie (2016), toż to najprzedniejsza wiwisekcja złożonego problemu chłopskości, jakiej zawodowa etnologia dotąd nie dostarczyła!

\section{W jakim stopniu możemy współcześnie mówić o dominujących stylach praktykowania antropologii; czy można by wskazać nurty i orientacje badawcze o charakterze paradygmatycznym?}

Tutaj odpowiem krótko. Podobnie jak dzieje się to w obrębie światowego i europejskiego kulturoznawstwa (zarówno w wariancie cultural studies, jak i badań w stylu niemieckim), antropologia jest dzisiaj zarażona poetyką kolejnych „zwrotów” teoretycznych, które wyznaczają puls badań. Ale żaden z nich - od refleksyjnego, przez piktorialny, pamięciowy, neuronaukowy czy jakie tam jeszcze się pojawiają, nie jest w stanie zdobyć dominującej pozycji. Żyjemy w stanie całkowitego rozproszenia pod tym względem. Jak się wydaje, wiąże się to ściśle ze słabnącą rolą humanistyki w neoliberalnej koncepcji świata. Walczymy o byt, walczymy o kurczące się środki i działamy zadaniowo, zgodnie z logiką grantowo-projektową. To nigdy nie sprzyja rozwojowi bardziej pogłębionej refleksji, niestety. Ale nie oznacza to, że ona nie istnieje; ginie jednak w codziennej krzątaninie i walce o przetrwanie.

\section{Jakie wyzwania stawia przed dyscypliną przyszłość?}

Przyszłości nie sposób przewidzieć. Mogę jedynie powiedzieć jedno: albo antropologia włączy się w krytyczną wiwisekcję neoliberalnego projektu globalnej monokultury kapitalizmu, albo jeszcze bardziej się zmarginalizuje. Zgodnie z mitem założycielskim naszej dyscypliny trzeba oddać głos słabym, nieuprzywilejowanym i tym wszystkim, którzy pozostają na marginesie głównej opowieści o współczesności. Wiedza musi mieć walor emancypacyjny, musi boleć i komplikować nasze życie, wytrącać z samozadowolenia. Takiej antropologii pragnę, o niej marzę nieustająco. Jak pisałem kiedyś, zajmując się kontrkulturą lat 60., warto przypomnieć Umberto 
Eco i jego nawiązanie do antropologicznej koncepcji kultury, ale na poziomie metajęzykowym. Jest to kultura rozumiana jako krytyczna definicja kultury dominującej i krytyczne uznanie pojawiających się kontrkultur. Kiedy Marks pisał Kapitał, stworzył kulturę w tym właśnie (a nie etycznym, estetycznym i antropologicznym) sensie. Co to oznacza? Eco nie ma wątpliwości: „Ten czwarty sens »kultury« jest zawsze, w pozytywnym sensie, kontrkulturowy. Stąd kontrkultura jest zaangażowaną krytyką albo transformacją istniejących paradygmatów społecznych, naukowych i estetycznych. Jest reformą religijną" (1995: 124). Rzecz w tym, że kultura dominująca toleruje pasożytnicze kontrkultury (czyni wręcz z tej zdolności wartość!). Z kontrkulturą mamy więc do czynienia wówczas, kiedy ktoś zmieniający kulturę, w której żyje, ma krytyczną świadomość własnych działań i jest w stanie wypracować teorię własnego odstępstwa od dominującego modelu, oferując przy tym model, który zdolny jest do przetrwania. Moim zdaniem to właśnie stara się od lat proponować David Graeber. Jednym słowem, warto wykorzystać „pierwiastek anarchistyczny”, który tkwi głęboko w antropologicznej wizji świata. Potrzebujemy krytycznej antropologii kultury jak nigdy dotąd. Jeśli uświadomimy sobie, że w Stanach Zjednoczonych, owym niegdysiejszym raju antropologicznych badań, prawie 70 procent Amerykanek i Amerykanów uważa uniwersytety za siedliska zła i rozsadnik niedobrych idei, miejmy świadomość, że świat, który próbowaliśmy budować drży w posadach i nie jest przesadą powiedzieć, że idzie nowe średniowiecze. Także dla nas.

\section{Bibliografia}

Eco, U. (1995). Does Counter-culture Exist? W: U. Eco, R. Lumley (red.), Apocalypse Postponed (115-128). London: Flamingo.

Osterhammel, J. (2013). Historia XIX wieku. Przeobrażenie świata (przeł. I. Drozdowska-Broering), Poznań: Wydawnictwo Poznańskie.

Trouillot, M.-R. (2003). Global Transformations. Anthropology and the Modern World. New York: Palgrave Macmillan. 
Mariusz Filip

mfilip@amu.edu.pl

Instytut Etnologii i Antropologii Kulturowej

Uniwersytet im. A. Mickiewicza

\section{Co to jest etnografia/etnologia/antropologia (jej miejsce wśród innych dyscyplin, cele, metody)?}

Zdefiniowanie różnic między etnografią, etnologią i antropologią zasługuje na osobną dyskusję, jednakże podążę tropem, w myśl którego terminy te odnoszą się do jednej dyscypliny, dalej zwanej przeze mnie krótko antropologią. W moim przekonaniu antropologia zajmuje w ramach zachodniej nauki miejsce szczególne, a to dlatego, że jej celem jest poznanie Innego, a więc społeczeństw czy społeczności - tradycyjnie: pozaeuropejskich, współcześnie: jakichkolwiek - które pojmują świat w sposób od naszego odmienny, nierzadko radykalnie obcy (różnica stanowi sedno antropologicznego rozumienia kultury). Tego rodzaju tubylcze wizje świata mogą stać w jawnej sprzeczności wobec wiedzy naukowej wypracowanej przez takie dyscypliny jak socjologia (która skupia się raczej na podobieństwie niż różnicy), historia czy filologia, ukazując ograniczenia użyteczności narzędzi rozumienia właściwych dla tych dyscyplin. Metoda etnograficznych badań terenowych, których prototypem pozostaje obserwacja uczestnicząca, pozwala doświadczać i wyjaśniać świat z perspektywy tubylca, w kategoriach jemu właściwych. Osobiście uważam, że sednem antropologii i tym, co stanowi o specyfice tej dyscypliny, jest imperatyw kwestionowania (zachodniej) wiedzy naukowej.

Skoro mowa była o metodzie, to nie można nie zauważyć, że w Polsce obserwacja uczestnicząca pozostaje stosunkowo rzadko wykorzystywanym narzędziem poznania Innego, zdecydowanie ustępując miejsca wywiadowi etnograficznemu, z którego coraz częściej robią użytek przedstawiciele innych dyscyplin. Oczywiście, wywiad pogłębiony zdecydowanie wystarcza do tego, aby móc uchwycić tubylczy punkt widzenia, ale skoncentrowanie uwagi na wypowiedziach informatorów znacząco ogranicza wgląd w rzeczywistość społeczną, zamykając oczy na pozajęzykowe wymiary kultury. Obserwacja uczestnicząca pozwala eksplorować niewypowiedziane (świadomie lub nie) wymiary rzeczywistości społecznej, które przez inne dyscypliny - skupione na słowie pisanym czy mówionym - są zwykle programowo ignorowane. (Rosnąca popularność psychoanalizy w badaniach humanistycznych nie zmienia w moim 
przekonaniu istoty rzeczy, a to dlatego, że jest ona zwykle używana jako narzędzie interpretacji, a nie pozyskiwania i analizy danych). Stoję na stanowisku, które reprezentują antropolodzy pokroju Edmunda Leacha, a obecnie Maurice'a Blocha, Kirsten Hastrup czy Judith Okely, że poznanie w antropologii nie odbywa się na poziomie języka, za pośrednictwem słów, lecz, niech będzie mi wolno powtórzyć własne słowa, „za sprawą ulotnego wyczucia, intuicji czy wrażliwości, powstających w toku osobistego, emocjonalnego, "cielesnego " doświadczania rzeczywistości społecznej”. W takim stylu antropologię uprawiali moi pierwsi przewodnicy po dyscyplinie (Tarzycjusz Buliński, Agnieszka Chwieduk i Mariusz Kairski) i oczywiście nie są jedyni.

\section{Jakie miejsce zajmuje w etnografii / etnologii / antropolo- gii kulturowej problematyka badań nad przeszłością?}

Do momentu przełomu postmodernistycznego, który polską antropologię dotknął w połowie lat 90. XX wieku, przeszłość - denotowana zwykle takimi pojęciami jak tradycja, historia czy po prostu ludowość - znajdowała się w centrum zainteresowania dyscypliny. $\mathrm{W}$ istocie, zmiany $\mathrm{w}$ sposobie uprawiania antropologii zasadzały się na zerwaniu z paradygmatem badań historycznych celem zorientowania na teraźniejszość. Konsekwencją tego stanu rzeczy jest marginalizacja w polskiej antropologii problematyki badań nad przeszłością, co dzieje się, jak uważam, ze szkodą zarówno dla antropologii, jak i historii. Nie od rzeczy będzie przypomnieć, że według Sherry Ortner historia stanowiła (poza granicami naszego kraju) alternatywny wobec praktyki symbol kardynalny antropologii lat 80 . i nie wydaje się, by temat ten stracił w jakiś szczególny sposób na znaczeniu.

Wróćmy jednak na grunt polski. Do niedawna prawdopodobnie większość antropologów zainteresowanych badaniami przeszłości wpisywała się (mniej lub bardziej) w tzw. nową etnologię polską zwaną inaczej antropologią kultury, której program sformułowany zaraz na początku lat 80. zakładał „antropologizację” polskiej etnografii/etnologii na bazie dokonań strukturalizmu i fenomenologii, w tym nouvelle historie, która skądinąd stanowi efekt antropologizacji klasycznej historiografii. Pomimo bezsprzecznej wartości i osiągnięć rzeczonej antropologii kultury, trudno traktować jej program jako antropologiczny sensu stricto. To raczej interdyscyplinarny charakter antropologii kultury stał się przyczyną jej popular- 
ności, zaś szczególnej atrakcyjności tego projektu dla historyków związanych choćby z czasopismem „Rocznik Antropologii Historii” - co wyraża się obecnością aż dwóch autorów programu w radzie naukowej rzeczonego czasopisma i wezwaniami wychodzącymi z tegoż środowiska do dalszej antropologizacji historii za pośrednictwem właśnie antropologii kultury (w istocie byłaby to antropologizacja historii antropologizującą historią) - tłumaczyć nie można niczym innym, jak właśnie silnym ukierunkowaniem strukturalno-historycznym, które to ukierunkowanie $\mathrm{z}$ antropologią strukturalno-historyczną Marshalla Sahlinsa ma niestety niewiele wspólnego. Fundatorzy kierunku podjęli w toku pierwszego dziesięciolecia swojej działalności kilka interesujących studiów nad przeszłością (L. Stomma, R. Tomicki), ale w późniejszym czasie ta orientująca się na szeroko pojęte kulturoznawstwo antropologia kultury nie przyniosła w tym zakresie zbyt wielu poważnych analiz (wyjątkiem od tej reguły jest na pewno P. Trzeszczyńska), a jedynie przyczynki, które zresztą zwykle miały charakter tyleż teoretycznych, co powierzchownych rozpoznań związków między historią i antropologią.

Przyczyn takiego stanu rzeczy upatrywałbym nie tylko w dokonującym się u końca XX wieku zwrocie polskiej antropologii ku teraźniejszości, ale także w zwrocie ku eseistyce i zatarciu granic między dyscyplinami. Byłbym skłonny twierdzić, że to właśnie z uwagi zarówno na przyczynkowy charakter, jak i zmąconą metodologię, studia antropologów kultury nad przeszłością nie zaoferowały ujęć konkurencyjnych wobec (antropologizującej) historiografii, lecz dobrowolnie ograniczały się do „dopełnienia" wiedzy historycznej, a w konsekwencji uznawały jej prymat nad wiedzą antropologiczną. Ośmielę się twierdzić, że większe osiągnięcia na polu poddawania w wątpliwość ustaleń historyków (i archeologów) miała „stara” etnologia polska, by wspomnieć tylko allochtoniczną koncepcję etnogenezy Słowian(K. Moszyński), tezę o apelatywności nazwy Kaszuby (A. Dobrowolska) czy, co prawda błędną, hipotezę o genezie wsi Kluki jako średniowiecznej osady rodowej (B. Stelmachowska).

Oczywistego remedium na słabość badań nad przeszłością prowadzonych w ramach antropologii kultury dostarcza metodologia właściwa antropologii kulturowej (społecznej). W istocie, polscy antropolodzy coraz częściej mierzą się z problematyką badań nad przeszłością w sposób, który bezpośrednio nawiązuje do dokonań światowej antropologii na polu studiów etnicznych i ekonomii politycznej, czyniąc swoim głównym przedmiotem dociekań tożsamość grup etnograficznych czy, mówiąc innymi słowy, ich historyczność w obu znaczeniach tego słowa: „obiektywnej” realności 
w procesie historycznym i „subiektywnego” (kulturowego) sposobu postrzegania procesów historycznych. W pierwszym rzędzie wypada wskazać opracowania, które dokonując weryfikacji statusu i historii grup zamieszkujących peryferia ziem polskich: Słowińców i Kaszubów (M. Filip), Hucułów (T. Kosiek) i w pewnym zakresie Bojków (K. Koziura) oraz zachodnią Amazonię: Remo i Capanahua (Ł. Krokoszyński), podejmują bezpośrednio dyskusję z ustaleniami historyków oraz tradycyjnych etnografów (w tym etnografów amatorów). Wspomnieć tutaj należy także opracowanie systematyzujące zróżnicowanie kulturowe Ameryki Środkowej i Południowej w perspektywie diachronicznej (M. Kairski). Dyskusję z dokonaniami historyków (i archeologów) podejmują także w Polsce antropolodzy zainteresowani studiami nad początkami państwa (A. Posern-Zieliński i M. Kairski), które w wy miarze empirycznym koncentrują się na przykładzie Polski (K. Pobłocki, M. Filip).

Największą popularnością cieszą się jednak badania lokalnych wyobrażeń na temat historii, jakie właściwe są z jednej strony, rozmaitym grupom etnicznym: amazońskim More (P. Chyc), andyjskim Kiczua (A. Przytomska), Tahitańczykom (M. Owczarska), mongolskim Torgutom(T. Rakowski) i Buriatom(Z. Szmyt), a z drugiej, grupom społecznym w rodzaju polskich leśników (A. Konczal) lub neopogan(M. Filip). Analogicznie rzecz się przedstawia w przypadku analiz pamięci Kozaków Zabajkalskich (I. Peshkov) czy polskich więźniów politycznych (A. Witeska-Młynarczyk). Do kategorii tej zaliczyć należy także eksploracje rekonstrukcji historycznych (K. Baraniecka-Olszewska) oraz lokalnych użyć obiektów takich jak dokumenty pisane (A. Halemba) czy pomniki (E. Klekot). Tego rodzaju studia poprzestają zwykle na przedstawieniu historii z punktu widzenia tubylca i nie wikłają się szerzej w dyskusję z przedstawicielami historiografii, chociaż zdarzają się od tej reguły wyjątki.

Przy tej okazji warto powiedzieć kilka słów o antropologii historii (historycznej) uprawianej przez historiografów, która od antropologii historii uprawianej przez antropologów - mimo pewnych niewątpliwych podobieństw - różni się mimo wszystko perspektywą badawczą, ukształtowaną w pierwszym rzędzie odmiennymi lekturami. W literaturze przywoływanej przez historiografów królują przecież klasycy nieklasycznej historiografii, zaś dorobek antropologiczny sensu stricto w zakresie badań przeszłości nie jest w nich uwzględniony właściwie w ogóle ${ }^{2}$. Koronnym argumen-

\footnotetext{
${ }^{2}$ Moje własne doświadczenia obcowania z antropologizującymi historiografami dowodzą zresztą, że znajomość dorobku antropologii anglosaskiej w zakresie badań nad przeszłością ogranicza się do raczej klasycznych prac antropologów amerykańskich, z przeoczeniem dorobku choćby K. Blu, J. Friedmana (i Szwedki K. Ekholm-Friedman) czy pracujących w Kanadzie M. Silverman i M.
} 
tem niech będzie fakt, że najczęściej przywoływany antropolog, Clifford Geertz, po pierwsze, nie specjalizował się w antropologicznych badaniach historii (za to idealnie wpisuje się w nurt strukturalny lansowany przez antropologię kultury), a po drugie, chociaż napisał to i owo z zakresu tej problematyki - by wspomnieć jedynie przetłumaczoną na język polski książkę Negara. Państwo-Teatr na Bali w XIX wieku (2006) - to nie te prace stanowią przedmiot odniesienia, lecz prawdopodobnie najsłynniejszy artykuł Geertza, w którym odniesienia do przeszłości są tyleż marginalne, co przypadkowe.

Warto zwrócić uwagę, że o ile w programach studiów historycznych kursy $\mathrm{z}$ antropologii historii/historycznej są coraz popularniejsze, o tyle w programie studiów etnologicznych kursów takich generalnie brak (zajęcia prowadzone przez moją skromną osobę pozwolę sobie pominąć).

\section{W jakim stopniu możemy współcześnie mówić o dominujących stylach praktykowania antropologii; czy można by wskazać nurty i orientacje badawcze o charakterze paradygmatycznym?}

W moim przekonaniu dominującym stylem praktykowania antropologii w Polsce jest współcześnie, przywołując słowa Tima Ingolda, „ontologiczne oddanie się” etnograficznym badaniom terenowym. Po okresie narastającej popularności antropologii refleksyjnej lub, jak kto woli, tekstualnej, ten styl uprawiania antropologii właściwie utracił swoją autonomię, stając się po prostu pewną fazą pracy antropologa, którą za C. Shore'em określić można mianem post-fieldwork. Niemniej w dalszym ciągu pewna grupa antropologów hołduje uprawianiu antropologii na sposób refleksyjny (m.in. W.J. Burszta, K. Kaniowska, W. Kuligowski, K. Majbroda, M. Mokrzan).

Współcześnie, nie tylko w polskiej antropologii, zamiast nurtów i orientacji badawczych w rozumieniu metodologicznym, dominują raczej nurty i orientacje

Lambeka. Z kolei prace antropologów brytyjskich - za wyjątkiem J. Goody'ego i może K. Hastrup pozostają niezauważone, a przecież sama Hastrup reprezentuje całą szkołę skupioną wokół afrykanisty E. Ardenera (choćby afrykaniści: J.D.Y. Peel i E. Tonkin oraz europeiści: M. Chapman, M. McDonald, S. Macdonald), są klasyczne prace antropologów ze szkoły manchesterskiej, takich jak J.A. Barnes (incydentalnie także V. Turner oraz E. Bott w Oceanii) i wielu innych pracujących zarówno w „egzotycznych” zakątkach świata (m.in. P. Gow, N.L. Whitehead, duet A. Strathern i P. Stewart, E.L. Hirsch, J. Carsten), jak i w „swojskiej” Europie (m.in. A. Jackson, J. Robin, C. Stewart, M. Stewart). Poza antropologią anglosaską niezwykle interesujący dorobek prezentuje przecież choćby antropologia francuska, m.in.: D. Berliner, D. Fassin, A.-C. Taylor i N. Wachtel. 
badawcze w rozumieniu przed miotowym; antropologii tego i owego mamy bez liku. $\mathrm{Na}$ tym tle wyróżnienie pewnych paradygmatów myślowych nastręcza niemało trudności, nie jest to jednak zadanie niewykonalne.

Na pierwszym miejscu wymienić zapewne trzeba antropologię krytyczną, która jako antropologia społecznie zaangażowana zasadza się z jednej strony, na dawaniu głosu i niesieniu pomocy grupom słabym (migrantom, tubylcom, kobietom), a z drugiej, na krytyce opresyjnego systemu (państwa, kapitalizmu itd.). Jest to prawdopodobnie najpopularniejszy paradygmat myślowy obecny w polskiej antropologii, który przenika poszczególne subdyscypliny antropologii.

$\mathrm{Na}$ drugim miejscu, z uwagi na teoretyczne znaczenie zwrotu ontologicznego, a wcześniej antropologii symetrycznej, wymienię jednym tchem nieporównanie mniejsze liczebnie: szkołę perspektywizmu indiańskiego Eduarda Viveirosa de Castro (M. Kairski, T. Buliński, F. Rogalski, K. Świerk, P. Chyc) oraz szkołę latourowską (A. Lis, M. Songin-Mokrzan). Obie te szkoły wydają się oddziaływać, w taki czy inny sposób, na kilka innych nurtów myślowych obecnych w polskiej antropologii.

Pełnymi garściami z nurtów składających się na zwrot ontologiczny czerpią: antropologia rzeczy (T. Rakowski, E. Klekot, W. Plińska, P. Cichocki), antropologia środowiskowa (A. Lis, A. Konczal) i antropologiczne studia nad zwierzętami (M. Kostecka).

Nurt antropologii fenomenologicznej (T. Rakowski, H. Patzer) rozwija się stosunkowo niezależnie od powyższych, nie sposób jednak nie zauważyć pewnych zbieżności między ideami perspektywizmu indiańskiego a paradygmatem ucieleśnienia. Biorąc pod uwagę, że cielesność stanowi rodzaj łącznika między szeregiem subdyscyplin antropologii: antropologia emocji i zwrot afektywny, antropologia religii, antropologia feministyczna i gender, antropologia sensoryczna, antropologia medycyny, antropologia jedzenia (m.in. R. Hryciuk, A. Kościańska, J. Lorenz, A. Niedźwiedź, M. Rajtar, A. Stanisz, A. Witeska-Młynarczyk), należałoby zastanowić się, podążając tropem S. Ortner, czy ciało nie stanowi symbolu kardynalnego dla teorii antropologicznej u początku XXI wieku. Osobno w tym miejscu należy wyróżnić nurt za swoją podstawę mający teorię praktyki P. Bourdieu, a także transakcjonizm F. Bartha (M. Chułek, M. Filip, M. Lubaś, A. Pasieka, M. Pawlak).

Tyleż niezależny, co niszowy paradygmat myślowy przedstawia flirtująca z naturalizmem nowa fala antropologii kognitywnej, która inspiruje się nie tyle językoznawstwem kognitywnym, co psychologią kognitywną i kognitywistyką w ogóle, reprezentowana m.in. przez M. Blocha, P. Boyera i D. Sperbera (A. Halemba, P. Chyc). 
Nie można zapominać o nurcie antropologii historycznej, któremu już wcześniej poświęciłem najwięcej uwagi.

Stosunkowo silny pozostaje także nurt antropologii, który kontynuuje tradycyjne podejście etnograficzne (opisowe), często ignorując (niemal) zupełnie osiągnięcia antropologii uprawianej poza granicami naszego kraju, w tym jednak przypadku trudno mówić o jakimś szczególnym paradygmacie myślowym.

\section{Jakie wyzwania stawia przed dyscypliną przyszłość?}

Antropologia w Polsce od dawna znajduje się na marginesie życia publicznego, zdecydowanie ustępując pola socjologii, psychologii czy kulturoznawstwu i wydaje się, że zwiększenie roli dyscypliny w debacie publicznej stanowi najbardziej palące zadanie. Nielicznym antropologom udaje się zwrócić uwagę na swoją pracę (warto wymienić tu nazwiska choćby A. Kościańskiej, K. Pobłockiego, T. Rakowskiego czy A. Stanisz), ale są oni w swoich działaniach niejako osamotnieni, gdyż w tym zakresie nie są prowadzone właściwie żadne działania o charakterze systemowym, chociaż z całą pewnością na uwagę zasługuje tutaj upublicznienie w ostatnim czasie przez polskie środowisko etnologów i antropologów polskich Manifestu etnologów i antropologów polskich przeciw dyskryminacji (Poznań, 23 listopada 2016), a wcześniej Stanowiska Polskiego Towarzystwa Ludoznawczego w sprawie przejawów ksenofobii i nietolerancji w Polsce (Lwów, 25 września 2015).

Pomimo tego, że od dwóch dziesięcioleci antropologia w Polsce (nie wspominając o reszcie świata) stanowi dyscyplinę par excellence społeczną, Komitet Nauk Etnologicznych PAN nie podjął żadnych działań mających na celu zmianę pozycji antropologii, która w ramach obecnej systematyki obszarów, dziedzin i dyscyplin naukowych w Polsce przynależy do dziedziny nauk historycznych. Problem ten może jawić się jako czysto formalny, jednakże nie pozostaje on bez wpływu na finansowanie badań antropologicznych przez Narodowe Centrum Nauki. Z kolei fizyczne umiejscowienie Instytutów, Katedr i Zakładów Etnologii i Antropologii Kulturowej w obrębie Wydziałów Historycznych nie sprzyja codziennemu przepływowi myśli naukowej między antropologami i choćby socjologami, a także narzuca poważne ograniczenia na proces dydaktyczny. 


\section{Grzegorz Godlewski}

grzegorzgodlewski@o2.pl

Instytut Kultury Polskiej

Uniwersytet Warszawski

Na początku chcę zaznaczyć, że nie jestem antropologiem, etnologiem ani etnografem - nie zdobyłem profesjonalnego wykształcenia w tych dziedzinach, nie mam też za sobą doświadczenia badań terenowych. Wiedzę antropologiczną uważam natomiast za podstawową w badaniach teoretycznych i wykorzystuję do konstruowania antropologicznej teorii kultury. Występując z tych pozycji, żywię nadzieję, że refleksje na temat stanu nauk antropologicznych formułowane nie z ich wnętrza, tylko z pewnego dystansu, mogą mieć jakąś wartość.

Zacznę od stwierdzenia, że od co najmniej trzech dekad antropologia ulega głębokim i daleko idącym przekształceniom, których następstw - nie mówiąc już o ostatecznych efektach - nie sposób jednoznacznie oszacować. Jedne z tych zmian wynikają ze szczególnych wyzwań, przed którymi stanęła antropologia (i antropolodzy); inne mają swoje źródło w ogólniejszych procesach rzutujących na kondycję nauki w ogóle, choć głównie nauk społecznych i humanistycznych.

Wśród tendencji ogólniejszych na plan pierwszy wysuwa się rozhermetyzowanie granic między dyscyplinami naukowymi. Nie chodzi już tylko o podejście inter-czy transdyscyplinarne; granice dyscy plin stają się przepuszczalne, a tym samym nie tylko ich ścisłe strzeżenie, lecz nawet respektowanie straciło na znaczeniu. Ale nie prowadzi to do całkowitego zatarcia tożsamości dyscyplin - inaczej się ją jednak definiuje. W szczególności badania antropologiczne od dłuższego czasu rozwijają się w przestrzeni wypełnionej przez wiele innych kierunków badania kultury - czasem jeszcze zachowujących status dyscypliny, ale częściej już do tego nie pretendujących. Wyznacznikiem takich „niezdyscyplinowanych” orientacji (przybierających postać różnego rodzaju „studiów nad...”) jest zwykle sam wybór obszaru dociekań, penetrowanego przy użyciu wszelkich dogodnych podejść, metod i narzędzi, bez względu na to, skąd są czerpane. Jeśli w tej konstelacji kierunków antropologia zachowuje odrębność - a moim zdaniem zachowuje i zachowywać powinna - to jej wyróżnikiem pozostają dwie właściwości: orientacja na Inność i Innego oraz opieranie się na badaniach terenowych, uznawanych, jak to określił James Clifford, za "praktykę dyscyplinującą". 
Na tak ramowo czy raczej brzegowo zakreślonym polu badań antropologicznych coraz mniejszą rolę odgrywają nadrzędne regulacje teoretyczne. Choć antropologia niemal od początku była nauką wieloparadygmatyczną, to w obrębie równolegle funkcjonujących paradygmatów siła ortodoksji bywała potężna. Zaczęła słabnąć, gdy zaczęto sobie zdawać sprawę, że model paradygmatyczny - dyktujący „zstępujący” porządek poznania, zgodnie z którym ogólna teoria wyznacza nie tylko metody i cele badań, ale również sposób definiowania tego, co może stać się ich przedmiotem prowadzi do poważnych ograniczeń i zniekształceń poznawanej rzeczywistości. Podejście systemowe pozostawia poza swoim zasięgiem w szczególności to, co składa się na realne życie kultury - co jest udziałem, jak mawiał Victor Turner, „żywych ludzi”. Porządek „zstępujący” jest więc coraz częściej zastępowany przez porządek „wstępujący", zgodnie z którym badacze, rezygnując ze wsparcia teorii paradygmatycznych, w pierwszym kroku otwierają się na wyzwania poznawcze samej rzeczywistości kulturowej i dopiero po rozpoznaniu napotkanych zadań konstruują swoje stanowisko badawcze ze składników dobranych stosownie do ich specyfiki, nie zaś z uwagi na jakąkolwiek ortodoksję teoretyczną czy dyscyplinarną.

To oczywiście tylko generalny wektor, reorientujący porządek dociekań. „Zwrot ku rzeczywistości", otwarcie na płynące z niej impulsy nie wyczerpuje kontrparadygmatycznej strategii poznania, która - jeśli nie ma prowadzić do rozproszenia i bezładu - musi kierować się wektorami bardziej konkretnymi. Najbardziej przekonującą, moim zdaniem, propozycję w tym względzie przedstawił Victor Turner, który uznał, że perspektywę „żywych ludzi” najlepiej reprezentuje wymiar doświadczenia kulturowego. Jego koncepcja antropologii doświadczenia - traktowanej nie jako dział antropologii, tylko jako nowa jej postać, wyzwolona z ograniczeń podejścia systemowego - pozostała jednak otwartym projektem, niezrealizowanym również przez tych, którzy próbowali podjąć jego ideę. Rzecz w tym, że choć dość powszechnie uznaje się, że bez uwzględnienia wymiaru doświadczenia - jak pisał Clifford Geertz - „każda analiza kulturowa wydaje się unosić kilka stóp nad ziemią”, to wymiar ten pozostaje w znacznej mierze niedostępny z zewnątrz i w związku $\mathrm{z}$ tym w niewielkim stopniu poddaje się operacjonalizacji badawczej.

Spośród różnych inicjatyw, które próbują zbliżyć się do sfery doświadczenia, mając przy tym na uwadze względną dostępność wskazanego przedmiotu badań, za najbardziej wydajne poznawczo i obiecujące uważam dwa kierunki. Pierwszy to zwrot ku badaniu praktyk kulturowych, zwłaszcza w tych realizacjach, które 
odwołują się do ujęcia praktyk przez Pierre'a Bourdieu - ujęcia radykalnego, stawiającego przed badaczami poważne wyzwania, jednak nawiązującego bliski kontakt z „kulturą żywą”, z obszarem „świata przeżywanego”. Ta ostatnia kategoria przywołuje drugi kierunek, który wydaje się spełniać wy mogi postparadygmatycznej, antysystemowej formuły antropologii: to fenomenologia, a raczej inspiracje fenomenologiczne w badaniach kultury. Chodzi tu, rzecz jasna, nie o bezpośrednią aplikację fenomenologicznego stanowiska filozoficznego, tylko o takie jego przekształcenie, by pozwalało docierać do tego, jak świat Innych jawi się im samym (nie zaś badaczowi czy innemu uniwersalizowanemu podmiotowi). Przyjmując perspektywę zadań stających obecnie przed antropologią, można by te dwa kierunki uznać za komplementarne: to, jak doświadczenie kulturowe ujawnia się i po części udostępnia poprzez praktyki, zyskuje uzupełnienie w tym, jak postrzeganie świata przez podmiot kształtuje się i manifestuje poprzez jego działania.

Oba te kierunki, ujmowane oddzielnie czy w zespoleniu, nie proponują gotowych metodologii ani nie oferują łatwego dostępu do tego, co chcą badać, choć nie są to trudności tak fundamentalne jak te, które powstają przy próbach badania doświadczenia. Trudności te wydają mi się jednak dowodem - i miarą - trafności wyboru drogi. Minęły bowiem czasy, gdy panowało przekonanie, że metody poznania wykształcone w nauce zachodniej oferują antropologom sposoby i środki rozpoznawania wszelkich postaci Inności kulturowej. Świadectwem tego są właśnie wskazane kierunki badań - zorientowane na praktyki i zorientowane fenomenologicznie - które łączy wyraźne odejście od postawy dominacji poznawczej w stosunku do przedmiotu badań, wyrastające między innymi z poważnego potraktowania znanej skądinąd prawdy, że cechą szczególną antropologii jako nauki jest to, że jej przedmiotem są inne podmioty. Stąd - choć również z innych, bardziej szczegółowych powodów - bierze się rekomendowane w obu tych kierunkach nastawienie na towarzyszenie badanym, opierające się na zawieszeniu wcześniejszych założeń poznawczych (w szczególności o charakterze paradygmatycznym) i przyjęciu postawy „uczonej niewiedzy”.

Strategia „towarzyszenia” ma tu jeszcze inne zastosowanie - tym razem w stosunku do teorii. Otóż zakwestionowanie nadrzędnej roli teorii systemowych nie oznacza, że teoria w jakiejkolwiek postaci traci w badaniach antropologicznych rację bytu. Uważam, że myśl teoretyczna zachowuje wagę, pozostając niezbędnym składnikiem podejścia naukowego, tyle że zmienia się jej funkcja. Wyrzekając się 
roszczeń paradygmatycznych, powinna teraz raczej towarzyszyć praktykom badawczym, sprawując ciągłą kontrolę prawomocności badań w miarę ich konkretyzowania się i rozwijania. Być może w tej funkcji jej rola staje nawet większa niż dotąd, a z pewnością większa staje się jej odpowiedzialność.

$\mathrm{Na}$ koniec jeszcze dwie uwagi - tym razem już tylko na prawach sygnału. Po pierwsze, przezwyciężanie podejścia systemowego winno opierać się na świadomości, że jego głównym źródłem jest zachodni tekstocentryzm, będące przejawem zaawansowanej piśmienności „nachylenie tekstowe”. Stąd przedsięwzięcia aspirujące do przekroczenia tego podejścia nie mogą poprzestawać na tradycyjnych tekstowych formach wyrażania i przedstawiania osiąganych w nowy sposób rezultatów. Odpowiednikiem kontrparadygmatycznego podejścia poznawczego jest kontrtekstowość, „pisanie inaczej”. Choć na gruncie polskiej antropologii takich prób nie ma jeszcze za wiele, to w obliczu potęgującego się kryzysu klasycznych a więc tekstowych - postaci reprezentacji poszukiwanie nowych sposobów pisania będzie z pewnością przybierać na sile.

I druga uwaga - dotycząca zaangażowania antropologii. Ostatnimi czasy to gorący temat, przedmiot żywych debat, w których głos zwolenników tak czy inaczej rozumianego zaangażowania staje się coraz donośniejszy. W tej kwestii zachowuję daleko idący sceptycyzm. Nikt dotąd nie podważył skutecznie poglądu, że nauka konstytuowana jest przez ideał poznania bezinteresownego i możliwie wiarygodnego. A skoro już sama obecność badacza zmienia stan badanych, to co dopiero jego czynne działanie w obrębie ich środowiska, wraz z nimi czy na ich rzecz. Nikt nie odmawia antropologom prawa do takich działań, również wykorzystujących wiedzę zdobytą podczas prowadzonych badań, ale działania te powinny być podejmowane poza samym postępowaniem badawczym, bo inaczej wiedza ta będzie naznaczona pozanaukowymi intencjami badacza i przez nie zniekształcona. 


\section{Katarzyna Kaniowska}

katarzyna.kaniowska@uni.lodz.pl

Instytut Etnologii i Antropologii Kulturowej

Uniwersytet Łódzki

\section{Co to jest etnografia/etnologia/antropologia (jej miejsce wśród innych dyscyplin, cele, metody)?}

Wszystkie pytania ankiety dotyczą właściwie jednego problemu, tj. samoidentyfikacji dyscypliny. W moim przekonaniu odpowiedź na te pytania powinna być poprzedzona dwiema uwagami o zasadniczym znaczeniu. Po pierwsze - użyty w pytaniach zapis „etnografia / etnologia / antropologia kulturowa” jest odzwierciedleniem założenia, że nasza dyscyplina ma trzy nazwy, których wolno używać zamiennie. Po drugie - zakłada się tu także, że o charakterystyce dyscypliny przesądzać ma zdanie tych, którzy ją uprawiają. Uważam, że już same te milczące założenia są znamienne i dobrze określają kłopoty z definiowaniem dziedziny nauki, jaką studiowaliśmy i jaką uprawiamy.

Użycie trzech terminów do określenia jednej dyscypliny jest świadectwem tego, jak trudno jej samej zakreślić swój obszar przedmiotowy i metodologiczną specyfikę. Być może dlatego w ankiecie znalazła się podpowiedź, by definiować tę dziedzinę nauki poprzez wskazanie „jej miejsca wśród innych dyscyplin, celów i metod”. Wydaje się jednak, że taki sposób określania dyscypliny jest pewną ucieczką przed analizą znaczeń używanych jej nazw. Jest dla mnie rzeczą oczy wistą, że etnografia, etnologia i antropologia kulturowa to osobne dziedziny naukowej refleksji i praktyki. Współcześnie słusznie zakładamy, że ich zakresy zachodzą na siebie; że wiedza i metody wypracowane przez każdą z nich służą analizom i badaniom pozostałych. Jednakże nie oznacza to, że stosowanie trzech terminów jako nazwy jednej dyscypliny lub też traktowanie ich jako synonimów czy nazw bliskoznacznych jest uprawnione. Sądzę, że kłopoty z nazwą naszej dyscypliny wynikają z jej historii oraz z zawsze obecnego (tak w przeszłości, jak i teraz) przeświadczenia o potencjale poznawczym znacznie większym od innych nauk o kulturze.

Z historii dziedziny wynika, że antropologia kulturowa wywodzi się z etnografii $i$ etnologii. Bez nich nie miałaby tego metodologicznego i teoretycznego zaplecza, które ukształtowało współczesną antropologię. Z pewnością zaplecze to rzeczywiście daje antropologii większe możliwości interpretacji badanych zjawisk. Ale 
zapytana o to, kim jestem nigdy nie powiedziałabym etnografem / etnologiem / antropologiem kultury. Myślę, że ścisły związek pomiędzy etnografią, etnologią i antropologią kultury raczej zakreśla horyzont poznawczy; daje możliwości, a nie jest koniecznością.

Ciekawe byłoby zanalizowanie związków pomiędzy kompetencjami każdej z tych nauk. To znaczy - etnografia daje mi jako antropologowi narzędzia i wiedzę, które niewątpliwie pozwalają szerzej i rzetelniej interpretować i diagnozować badane przeze mnie zjawiska, podobnie etnologia. O ile etnografia jest mi w antropologii najczęściej niezbędna do udokumentowania prowadzonych analiz, to etnologiczne badania niekoniecznie. Zatem można utrzymywać, że - w jakimś sensie - etnografia i etnologia pełnią funkcję służebną wobec antropologii kultury. Zachowując swą autonomię, poszerzają możliwości antropologii. Co znaczące, relacja pomiędzy wszystkimi tymi dziedzinami jest taka, że ze wszystkich trzech tylko etnografia nie potrzebuje pozostałych; etnologia i antropologia bez etnografii są nie do pomyślenia. Jednak ta ścisła zależność nie uprawnia do stosowania trójczłonowej nazwy dyscy pliny. Uważam, że spopularyzowanie takiej nazwy przyczyniłoby się do jeszcze większych kłopotów z identyfikacją dyscypliny w odbiorze społecznym. I tak jest $\mathrm{z}$ tym problem.

Założenie, iż charakterystyka dyscypliny będzie trafna i pełna (tj. wyraźnie nakreśli pole zainteresowań, cele badawcze i metodologiczną specyfikę) wtedy, gdy sporządzą ją ci, którzy ją uprawiają, jest oczywiście uzasadnione. Ale trzeba pamiętać, że antropologia została zawłaszczona przez dziedziny pokrewne i wobec tego w jej identyfikacji warto byłoby uwzględnić wyobrażenia i praktyki podejmowane poza środowiskiem antropologów. W wielu programach studiów humanistycznych antropologia jest wykładanym przedmiotem i wielu nie-antropologów z wykształcenia uważa się za antropologów.

Zastanawiam się, czy ten fakt ma za swą przyczynę nie dość wyrazistą samoidentyfikację polskich antropologów, czy też jest to konsekwencja procesów nieuniknionego mieszania się dyscyplin. To pierwsze znajduje potwierdzenie w trwających wiele lat dyskusjach o tożsamości antropologii. Dziś wprawdzie debata ta przycichła i - jak się zdaje - zainteresowanie antropologów zwróciło się w kierunku badań subdyscyplinarnych, ale sprawa definiowania własnej dyscypliny nadal jest problemem, czego dowodem jest rozpisanie niniejszej ankiety. To drugie zaś, czyli zapożyczanie metodologicznych perspektyw i wspólnota pewnych celów poznawczych, stało się 
współcześnie cechą powszechną humanistyki i nauk społecznych. Antropologia od dawna (by nie powiedzieć - zawsze) korzystała z koncepcji teoretycznych i metodologicznych wypracowanych przez inne dyscypliny lub przejmowała i adaptowała na swój użytek intelektualne nurty europejskiej i amerykańskiej myśli filozoficznej czy społecznej. Od dawna też widoczny jest ruch odwrotny - inne dziedziny nauki badające zjawiska kulturowe i społeczne sięgnęły do koncepcji i praktyki antropologii. W moim przekonaniu jest to proces charakterystyczny dla współczesnej wizji nauki. Nie tak dawno postulowana interdyscyplinarność poznania naukowego stała się dziś standardem, co zaowocowało nie tylko łączeniem doświadczeń i działań różnych dyscyplin, ale też dało początek idei transdyscy plinarności, której próby we współczesnej humanistyce są już podejmowane. Otwartość antropologii na inne nauki uznawana wcześniej za wyjątkowy przymiot wyróżniający ją spośród innych nauk o kulturze - choć pozostaje jej cechą - nie jest już tak wyjątkowa.

Dziś jedyną, jak sądzę, rzeczywistą antropologii wartością, która pozwala utrzymać jej tożsamość, w grupie dyscyplin o takich samych lub daleko podobnych celach poznawczych i obszarze zainteresowań, jest metoda etnograficznych badań terenowych. Za cechę stanowiącą o tożsa mości antropologii i różniącą ją od innych nauk uznaję również trwale w antropologii deklarowany przedmiot badań, jakim jest człowiek i jego kultura. Takie określenie przedmiotu pozwala na szersze i odmienne niż gdzie indziej rozpatrywanie kultury, bowiem w badanach i analizach antropologicznych patrzymy na nią jako na dziedzinę ludzkich doświadczeń. Doświadczenie jest - w moim przekonaniu - kluczową kategorią we wszelkich interpretacjach antropologicznych. Tym samym można by powiedzieć, powtarzając za wieloma mistrzami antropologii, że antropologia jest nauką opisującą i tłumaczącą wielość i różnorodność sposobów rozumienia i przeżywania świata przez ludzi.

\section{Jakie miejsce zajmuje w etnografii / etnologii / antropologii kulturowej problematyka badań nad przeszłością?}

Sądzę, że zainteresowanie przeszłością kształtuje się współcześnie rozmaicie w każdej z trzech dyscyplin - etnografii, etnologii i antropologii. Ale generalnie rzecz biorąc w ramach każdej z nich obserwujemy tę samą tendencję, tj. zwrócenie się w badaniach ku zjawiskom i procesom rozgrywającym się aktualnie, a nie w przeszłości. Przeszłość jest przedmiotem badań o tyle, o ile jest ona konieczna do charakterystyki 
badanych zagadnień. Widać też przy okazji, że owo przesunięcie pól zainteresowań zmienia każdą z dziedzin. I tak etnografia redukowana bywa do metody (mamy tego liczne przykłady w socjologii i kulturoznawstwie); etnologia staje się uzupełnieniem badań antropologii fizycznej czy archeologii (to z kolei widać w anglosaskich badaniach pozaeuropejskich lub projektach transdyscyplinarnych, których w Polsce wciąż brakuje); zaś antropologia skupiła się na problematyce pamięci. Uważam, że badanie pamięci przyniosło antropologii spore korzyści. Z jednej strony, pozwoliło wyzwolić pewien potencjał tkwiący we wcześniejszym dorobku teoretycznym i metodologicznym oraz upowszechnić wiedzę o pamięci, jaką antropologia wytworzyła, zanim w humanistyce dokonał się „zwrot pamięciowy”. Z drugiej, pozwoliło to także na wcześniej nieistniejące zbliżenie pomiędzy antropologią a innymi dyscyplinami humanistyki, zainteresowanymi badaniami przeszłości jako pamięci. Stąd tak liczne i niezwykle owocne dla dyskursu pamięciowego badania łączące koncepcje wypracowane na gruncie historii, socjologii z interpretacjami kulturoznawczymi i literaturoznawczymi. Antropologia w tym dyskursie ma - w moim przekonaniu znaczący udział. Nie tylko dlatego, że wskazała rozległe możliwości badania pamięci, ale także dlatego, że przyczyniła się do definiowania samej tej kategorii.

\section{W jakim stopniu możemy współcześnie mówić o dominujących stylach praktykowania antropologii; czy można by wskazać nurty i orientacje badawcze o charakterze paradygmatycznym?}

Jesteśmy obecnie w niezwykle interesującej fazie rozwoju dyscypliny. Po wzmożonym zainteresowaniu poszukiwaniem paradygmatów, co wpisane było w dyskusję o tożsamości antropologii, pojawiła się wyraźna tendencja, zmieniająca dotychczasową praktykę. Widać to w tworzeniu (lub istotnym wzmacnianiu już istniejących) obszarów szczegółowych zainteresowań badawczych. W konsekwencji antropologia rozbita zostaje na subdyscypliny; antropologie określone rodzajnikiem. Każda z nich zarysowuje swoje pole badawczej eksploracji, próbując jednocześnie wskazać pożytki płynące z zastosowania na tych polach metod etnograficznych i interpretacji antropologicznych. Wydaje się więc, że analizy antropologiczne koncentrują się dziś na wybranych zjawiskach czy obszarach kulturowych, rozgrywających się współcześnie. Oznacza to, że zmieniły się strategie tłumaczenia zjawisk kulturowych 
podejmowane przez antropologów - rekonstrukcje ustąpiły pola konstrukcjom; pytanie o to „jak było”, zastąpiło pytanie „jak jest”.

Nie zmienił się oczywiście naczelny cel poznawczy. Jest nim nadal poszukiwanie najtrafniejszych, najbardziej przekonujących interpretacji, które pozwoliłyby zrozumieć otaczający nas świat, tj. wyjaśnić jak i dlaczego w taki właśnie sposób przebiega ludzkie doświadczenie. Jest rzeczą interesującą i to zapewne w największej mierze zadecyduje o najbliższej przyszłości naszej dyscypliny - jak rozwijać się będą antropologie przedmiotowe. Ich wydzielenie się jako subdyscyplin jest metodologicznym wyzwaniem, bowiem z jednej strony, każda z nich - z konieczności - operuje nieco innym językiem pojęć i ze względu na przedmiot swoich badań musi stosować określone ramy interpretacyjne, z drugiej zaś - zachować teoretyczne i metodologiczne standardy współczesnej antropologii. O ile to drugie stosunkowo łatwo zachować (i tu potwierdza się w pełni wcześniej przytoczone przeze mnie przekonanie, że jedną z podstawowych cech tożsamościowych naszej dyscypliny jest etnograficzna metoda badań terenowych), wykorzystując metody badawcze wytworzone przez antropologię, to jednak sprawa wpisywania się subdyscyplin w określone nurty czy orientacje teoretyczne jest poważnym problemem.

Sądzę tak dlatego, że - w moim przekonaniu - w antropologiach przedmiotowych nie istnieje potrzeba ustaleń paradygmatycznych. Porządek działania naukowego określany jest przedmiotem badań i celami badawczymi. Dobór ram interpretacyjnych i metod jest drugim, a nie pierwszym krokiem w tym działaniu. Być może jest to w jakiejś mierze konsekwencja (tymczasowego?) odwrotu od poszukiwania paradygmatu; uznania, że wobec wielości nurtów i orientacji naukowych humanistyka, w tym oczywiście także antropologia, nie ma potrzeby (bo nie ma konieczności) tworzenia nowych paradygmatów, a istniejące wolno wykorzystywać bez większego lęku o konsekwencje przekraczania granic określonych teorii, koncepcji czy metod. Przeciwnie, owo przekraczanie staje się zaletą, bo zgodne jest z złożeniem o potrzebie i naukowej wartości transdyscyplinarnych, a wewnątrz dyscyplin „transnurtowych" modeli działań badawczych. Uważam, że to bardzo interesujący moment w historii antropologii. Z niedawnych sporów o tożsamość przeszliśmy do skupienia się na badaniach konkretnych fragmentów współczesnej rzeczywistości kulturowej i próbujemy tłumaczyć je wszelkimi dostępnymi i sprawdzonymi już sposobami. Zdecydowana większość badań z zakresu antropologii przedmiotowych przyczynia się do znaczącego i przekonującego tłumaczenia faktów czy procesów, które są ich przedmiotem. Pojawiają się zatem 
pytania, niezwykle istotne z punktu widzenia metodologii, czy antropologia w istocie potrzebuje jasno określonych ram paradygmatycznych; czy w poszukiwaniu tożsamości antropologii sprawa identyfikowania się dyscypliny z nurtami lub badawczymi orientacjami jest najlepszym tropem? Jeśli wziąć pod uwagę te wątpliwości, to warto dostrzec, jak bardzo zmienia się tym samym kwestia naukowości antropologii.

Oznacza to, że trzeba szukać innych gwarancji naukowego statusu antropologii niż te, na które powoływaliśmy się wcześniej. Wydaje się, że wobec obserwowanych zmian nie tylko trzeba inaczej myśleć o antropologii, ale zarazem zmienić trzeba „taktykę" poszukiwania jej tożsamości. W obecnej sytuacji - jak mi się wydaje jedynie metodologia może identyfikować naszą dyscyplinę. Cechą konstytutywną antropologii, cechą, która odróżnia ją od wszystkich innych nauk o kulturze, jest więc sposób badania, a nie przedmiot czy obszar zainteresowań lub cele badawcze. Sposób badania rozumiem szeroko, nie tylko jako wybór metod i całej strategii postępowania badawczego, ale też podjęcie decyzji o wyborze ram interpretacyjnych. Nade wszystko zaś wszystkie te wybory muszą wynikać z przyjęcia określonej koncepcji antropologicznej, która pozostaje w zgodzie z wymogami naukowości. Tylko wtedy antropologia zachowa swą tożsamość jako dyscyplina nauki.

Sądzę, że aktualny stan rzeczy w antropologii (nie tylko w Polsce) wskazuje, że współczesnej antropologii nie interesuje poszukiwanie teorii kultury, co uważam za zrozumiałe. Aktualny stan rzeczy charakteryzuje wielość orientacji badawczych i nurtów. Jak zaznaczyłam wcześniej, jesteśmy obecnie w takim okresie rozwoju dyscypliny, w którym antropologię rozumie się jako naukę opierającą swą wiedzę o empiryczne badania współcześnie dziejących się zjawisk i procesów. Antropologia współcześnie stawia sobie za zadanie główne tłumaczenie tego, co wokół nas się dzieje. Stąd tworzenie się i rozwój subdyscyplin; specjalizowanie się w badaniu i analizach wybranych dziedzin życia. Można by powiedzieć, że cele zasadnicze dyscypliny nie zmieniły się - nadal chodzi nam o zrozumienie ludzkich działań i sposobów myślenia w wielu istniejących wariantach. Zmieniła się natomiast skala poznania. Zmniejszyła się ona do konkretnych, dających się wyodrębnić obszarów ludzkiej aktywności. Owszem, każdy z tych obszarów trzeba tłumaczyć uwzględniając możliwie najszersze pola odniesień, jednak antropolodzy wolą być dzisiaj badaczami-znawcami jakiejś dziedziny życia nie zaś autorami teorii kultury czy refleksji o współczesnej kondycji człowieka i jego świata. Antropolog jest dziś raczej specjalistą, a nie myślicielem. 
Nie bez przyczyny używamy teraz najczęściej zwrotu „praktykowanie antropologii”. To oznacza, że zainteresowani jesteśmy obecnie empirycznym poznaniem. Widzę w tym tryumf metody etnograficznych badań terenowych jako cechy tożsamościowej antropologii. Osobnym, ciekawym zagadnieniem jest to, co spowodowało ten zwrot ku konkretowi w antropologii? Czy taka jest tzw. potrzeba chwili, to znaczy, czy zmiany następujące we współczesnym świecie wymagają podpowiedzi antropologa, jak je rozpoznawać i jak rozumieć, bo inne dyscypliny nie dość je wyjaśniają? Czy też - zmiany te spowodowane są wewnętrznymi przekształceniami w obrębie dyscypliny, w wyniku których po etapie poszukiwań wzorów makrointerpretacji nastąpił zwrot ku empirii. Empiryczne poznanie zawsze było w antropologii obecne. Od czasu ustanowienia metodologicznych standardów przez Malinowskiego, antropologia opierała swa wiedzę na fundamencie empirycznego zbadania ludzkich doświadczeń. Jednakże badania takie najczęściej pełniły rolę służebną wobec ogólniejszych interpretacji, dotyczących całości danej kultury, badanej kategorii czy typu jakiś zjawisk. Jak mi się zdaje, taka perspektywa z rzadka interesuje współczesnych antropologów.

Badania empiryczne stały się obecnie autoteliczną wartością i podejmowane są w przekonaniu, że dają wiedzę pewną, która nie potrzebuje odniesienia czy ugruntowania $\mathrm{w}$ jakichś określonych paradygmatycznych ramach. Tym, co w większej mierze zarysowuje pole odniesienia badań, jest dziś raczej polityczna czy światopoglądowa postawa badacza. Oczywiście, można twierdzić, że wszystko, co kulturowe i społeczne jest polityczne, ale jest to stwierdzenie dotyczące cechy przedmiotu, nie zaś cechy refleksji o przedmiocie. Stąd też interesujące jest dla mnie pytanie o to, czy taka zmiana funkcji badań empirycznych, zmiana w postrzeganiu statusu poznania empirycznego będzie nową siłą antropologii i czymś, co wyraźniej zdefiniuje jej tożsamość czy też pozostanie charakterystyczną cechą pewnego etapu rozwoju dyscypliny.

\section{Jakie wyzwania stawia przed dyscypliną przyszłość?}

Pytanie postawione powyżej jest po części także pytaniem o przyszłość dyscypliny. Nie ma wątpliwości, że rzeczywistość społeczna i kulturowa będzie nadal podlegać szybkim i głębokim przemianom. Nie ma też wątpliwości, że antropologia będzie te przemiany badać. To oznacza, że antropologia zajmować się będzie aktualnymi, 
a nie przeszłymi kulturowymi zjawiskami. Będzie nauką tłumaczącą i interpretującą współcześnie dziejącą się rzeczywistość. O ile - jak mi się zdaje - łatwo przewidzieć przyszły przedmiot zainteresowań dyscypliny, to metodologiczne ewentualne zmiany już mniej. Zasadniczą kwestią decydującą o przyszłości antropologii jest wypracowanie przez nią takich sposobów badania i interpretowania, które będą rzeczywiście służyły wyjaśnianiu przyszłej rzeczywistości. Z obecnego stanu rzeczy można wnioskować, że w najbliższym czasie utrzyma się tendencja rozwijania się antropologii przedmiotowych. Wydaje mi się też, że będzie się również umacniało przekonanie o konieczności angażowania się antropologii w procesy społeczne i kulturowe oraz uczestnictwa w rozwiązywaniu konfliktów społecznych. Jeśli przewidywania te są trafne, to będziemy świadkami nowego przełomu, a mianowicie zmian w metodologii antropologii, jakie wywoła już zapoczątkowany zwrot etyczny. Bez pogłębionej etycznej refleksji nie uda się sprostać metodologicznym problemom, jakie towarzyszą nauce wszędzie tam, gdzie ogląd badanego przedmiotu nie odbywa się z metapoziomu, ale z najbardziej bliskiej perspektywy. Z pewnością też antropologia najbliższej przyszłości nadal będzie chłonąc inspiracje płynące $\mathrm{z}$ całego obszaru humanistyki. Jednakże w większym stopniu będzie to dzielenie wspólnych zainteresowań i problemów, niż przejmowanie i adaptowanie koncepcji powstałych poza antropologią. Przeciwnie - toczący się już proces tzw. antropologizacji dyscyplin pokrewnych pozwala przypuszczać, że antropologia może stać się dyscypliną więcej znaczącą w humanistyce niż dotychczas. Ale taka diagnoza sprawdzi się tylko wtedy, gdy najwięcej uwagi poświęcimy refleksji metodologicznej. 


\section{Waldemar Kuligowski}

walkul@amu.edu.pl

Instytut Etnologii i Antropologii Kulturowej

Uniwersytet im. Adama Mickiewicza w Poznaniu

\section{Co to jest etnografia/etnologia/antropologia (jej miejsce wśród innych dyscyplin, cele, metody)?}

Zmieniają się wielorakie warunki zewnętrzne, status humanistyki, znaczenie uniwersytetów - zmienia się i nasza dyscyplina. Choćby i tym wymiarze, że nigdy wcześniej nie uprawiało jej tylu badaczy, że nie nauczano jej na tak wielu uczelniach wyższych, że nie angażowała tylu organizacji i stowarzyszeń. Przedmioty badań antropologii zanikają i wyłaniają się, jej metody ulegają zmąceniom i wyklarowaniom, dyslokuje się i sedentaryzuje także jej dziedzictwo. Pewien rdzeń dyscypliny można jednak opisać tak samo niemal, jak przed laty: antropologia to najbardziej ogólna ze szczegółowych nauk o człowieku, badająca sensy nadawane rzeczywistości przy użyciu metod empirycznych, gdzie grecki termin „empeiria” oznacza „doświadczenie”.

\section{Jakie miejsce zajmuje w etnografii / etnologii / antropolo- gii kulturowej problematyka badań nad przeszłością?}

W systemie polskich uniwersytetów publicznych jednostki prowadzące badania etnologiczne/antropologiczne ulokowano na wydziałach historycznych (albo z historią, obok innej dyscypliny, w nazwie). W państwowym systemie grantowym również przy pisano nas do branży „wiedza o przeszłości” (znamienne HS3 w Narodowym Centrum Nauki). Pytanie o to, jakie miejsce zajmuje problematyka badań nad przeszłością w tym kontekście wygląda na niemal retoryczne. Na szczęście to tylko jedna warstwa struktury, będąca tyleż efektem akademickiej inercji, co i spuścizny po innym systemie ustrojowym. Kolejne warstwy - podejmowane badania, realizowane granty, tematyka zajęć dydaktycznych, tytuły publikowanych prac, tematyka organizowanych konferencji - pozwalają na myślenie o uwolnieniu się od bycia „nauką pomocniczą historii” (jak w PRL) lub dyscypliną zorientowaną na „etnografię ratowniczą" i paradygmat ocalania. Tym, co wymaga ocalania i ratowa- 
nia jest bowiem teraźniejszy stan kultury badanej przez antropologów. Przeszłość poradzi sobie sama, ma wszak innych, możniejszych patronów.

\section{W jakim stopniu możemy współcześnie mówić o dominujących stylach praktykowania antropologii; czy można by wskazać nurty i orientacje badawcze o charakterze paradygmatycznym?}

Jedynym paradygmatem, który z powodzeniem przyswoiła polska etnologia/antropologia jest pozytywizm i postpozytywizm. To rzutuje na dominację obiektywistycznego modelu poznania, korespondencyjnej koncepcji prawdy oraz przekonania o istnieniu neutralnych opisów i adekwatnego języka reprezentacji. Doniosłe zwroty - relatywistyczny, etyczny, postmodernistyczny - zostawiły pojedyncze i nieciągłe ślady. Sięgając po analogię z zakresu historii filmu powiedziałbym, że o ile do lat 70. dominowało wśród badaczy kino realistyczne, o tyle obecnie obok niego pojawił się neorealizm. Chcemy nie tylko adekwatnie przedstawiać, ale także skutecznie poruszać losem przedstawionych. Jak u Viscontiego i De Siki, dramaty pojedynczych wykluczonych bądź dyskryminowanych urastają do rangi generalizacji, będącej wstępem do krytyki liberalizmu/kapitalizmu (czasem również globalizmu, turyzmu, seksizmu itp.). Inna sprawa, że krytyka kulturowa w Polsce właściwie raczkuje, dlatego niektóre teksty i opinie antropologów wydają się w debacie publicznej nadzwyczaj kontrowersyjne. I nie należy z tego narzędzia rezygnować.

\section{Jakie wyzwania stawia przed dyscypliną przyszłość?}

Trzeba nieustannie pracować nad tym, by przestać być ekspertem od festiwali i świąt, pożądanym w mediach od końca października do Nowego Roku, a potem od końca karnawału do Wielkanocy. To zniekształca obraz dyscypliny, ponownie zsyłając ją do poziomu „wiedzy o przeszłości”. Trzeba podjąć zdecydowane działania na rzecz innego usytuowania dyscypliny w kategoryzacjach państwowych grantodawców. Trzeba publikować o sprawach dotyczących i obchodzących grona szersze niż te, które interesują się tanią egzotyką: czy to obcą, czy swojską. Trzeba angażować się w debaty publiczne, by dzięki wykorzystaniu dorobku oraz narzędzi dyscypliny formułować ważne i znaczące sądy. Trzeba ciągle mierzyć się z wyzwaniami współczesności, takimi jak sieć WWW, rynki kapitałowe, nowe formy władzy, prawa, 
wymiany, własności, pokrewieństwa. Trzeba eksperymentować na gruncie metodologii i na poziomie przekazu, a medium dominującym wcale nie musi pozostać druk. Trzeba być aktywnym, sprawczym i frapującym dla innych. W przeciwnym wypadku najpierw zabraknie studentów, potem funduszy, a wreszcie akceptowalnej dla innych racji wyjaśniającej nasze dyscyplinarne istnienie.

\section{Marcin Lubaś}

marcin.lubas@uj.edu.pl

Instytut Socjologii

Uniwersytet Jagielloński

\section{Co to jest etnografia/etnologia/antropologia (jej miejsce wśród innych dyscyplin, cele, metody)?}

Spróbuję odpowiedzieć w odwrotnej kolejności. Antropologia to jedna z nauk zajmujących się człowiekiem. Przy tym zainteresowanie antropologii ludźmi jest zastanawiająco wszechstronne. Interesuje nas przeszłość, teraźniejszość i przyszłość człowieka, jego/jej historia i ewolucja, życie społeczne, psychiczne, biologiczne, środowiskowe, wariantywność sposobów ludzkiego życia w przestrzeni, modalności zmian, jakim ulega ono w różnych skalach czasowych. Antropologia była i jest nadal nauką poszukującą, stąd tak silny i nieprzerwany nacisk na wykorzystywanie intensywnych badań terenowych i etnografię w procesie tworzenia i kumulacji wiedzy antropologicznej. Nie należy - chociaż niekiedy tak czyniono - utożsamiać tego nastawienia na poszukiwanie z upodobaniem do egzotyki, pierwotności, archaiczności. Ważnym - może nawet najważniejszym - zagadnieniem w antropologii jest pytanie o przyczyny zmian, jakim ludzkie życie podlega, podlegało i podlegać będzie w całej jego kompleksowości i rozmieszczeniu na powierzchni Ziemi.

Jest to wciąż pytanie otwarte. Podejmowa ne przez antropologów/antropolożki próby, mniej lub bardziej, pełnej odpowiedzi na to pytanie cechuje jednak na ogół pewna ostrożność. Poznawanie ludzkiego życia wymaga jego gruntownego zrozumienia (co jest mozolnym, narażonym na błędy procesem), a następnie ujęcia $\mathrm{w}$ terminach opisów i wyjaśnień, z jakich korzysta się w pracy naukowej. Prowadzi to niekiedy do kwestionowania samych pojęciowych ram opisu i wyjaśnienia, a cał- 
kiem często do rewizji i modyfikowania aparatu pojęciowego oraz metodologicznego nauki. Publiczną rolą antropologii pozostaje krytyka etnocentryzmu jako postawy ograniczającej dostęp do wiedzy i praktyczna znajomość ludzkiej różnorodności, jej uwarunkowań i konsekwencji. Jak każda nauka akademicka antropologia jest silnie zinstytucjonalizowanym obszarem działalności poznawczej. Warunkiem instytucjonalnego i intelektualnego bytu antropologii oprócz uniwersytetu były i są struktury polityki państwowej oraz społeczne relacje władzy i stosunki ekonomiczne. Europejski kolonializm i kapitalizm stanowiły na przykład instytucjonalne i ideowe zaplecze dla XIX- i XX-wiecznej antropologii. Czy oznacza to, że antropologia była, czy jest, praktyką wspierającą politykę imperialną czy interesy biznesu? Z perspektywy czasu widać, że zdarzało się to w historii dyscypliny niejednokrotnie. Zależność od polityki państwowej i elit ekonomicznych nie musi oznaczać uległości naukowców/naukowczyń względem różnych aparatów władzy. Przynajmniej część środowiska naukowego wypracowuje czy wywalcza sobie autonomię, pozwalającą na prowadzenie zdecydowanej krytyki polityki imperialnej oraz gospodarki opartej na eksploatacji.

Etnologia to określenie uznawane obecnie za synonim słowa antropologia, ale może również oznaczać ludoznawstwo studiujące kulturę ludową. Jak wiadomo w niemieckiej tradycji naukowej istnieje opozycja między Völkerkunde (etnologią badającą społeczeństwa pozaeuropejskie) i Volkskunde (ludoznawstwem studiującym rodzimą kulturę ludową, chłopską). Opozycja ta wydaje mi się znacznie mniej wyrazista jeśli chodzi o Polskę. Tradycja ludoznawcza z wielu względów jest jawnie kontestowana przez niektórych badaczy i niektóre badaczki określających się jako etnolodzy/etnolożki/antropolodzy/antropolożki, ale nie jest jednak całkowicie przez środowisko etnologiczne odrzucana. Nie ma podstaw do kwestionowania empirycznych dokonań ludoznawstwa, ale pojawia się oczywiście pytanie o związek ludoznawczo zorientowanej etnologii czy ludoznawstwa w Polsce z projektami narodowotwórczymi i polonizacyjnymi zarówno przed, jak i po drugiej wojnie światowej. Oczywiście jest to pytanie, które należy postawić historykom/historyczkom badającym najnowsze dzieje wielu innych dyscyplin (w tym oczywiście historii, pedagogiki, socjologii), ale unikanie refleksji na ten temat, gdy chodzi o etnologię i ludoznawstwo, byłoby równie błędne, co unikanie namysłu nad antropologią kolonialną i związkami antropologii z polityką imperialną. 
Trzeci z terminów - etnografia - oznacza zbiór technik opisu życia ludzkiego opierających się na współuczestnictwie badacza/badaczki w określonych aktywnościach specyficznej grupy lub kategorii ludzi. Jako metoda etnografia jest stosowana w wielu naukach społecznych, wydaje się jednakowoż nieodzowna w badaniach antropologicznych, ponieważ jest zbiorem technik eksploracyjnych zorientowanych na odkrywanie różnych powiązanych ze sobą aspektów ludzkiego bytu. Nie oznacza to, by każdy antropolog i każda antropolożka musieli osobiście prowadzić badania etnograficzne, każdy/każda reprezentant/reprezentantka antropologii musi wszelako jako element nabywania wiedzy antropologicznej studiować opisy etnograficzne sporządzone przez innych badaczy / inne badaczki. Ważnym elementem etnograficznej pracy badawczej jest autorefleksja moralna, rozwój wrażliwości moralnej badaczy/badaczek pozwalającej bardziej zdecydowanie reagować na dobro i zło.

\section{Jakie miejsce zajmuje w etnografii / etnologii / antropolo- gii kulturowej problematyka badań nad przeszłością?}

Już Edward Evans-Pritchard zauważył, że bez znajomości przeszłości i wiedzy historycznej refleksja teoretyczna w antropologii nie będzie miała potwierdzalnych podstaw. Tylko dzięki znajomości przeszłości i wiedzy historycznej możemy pytać o naturę i przebieg zmian, jakim podlega człowiek. Zaryzykowałbym zdanie, że to właśnie historia społeczna pozwoliła antropologii wykroczyć poza ramy teorii społeczeństwa pierwotnego i poważnie zainteresować się zmianami społecznymi zarówno zachodzącymi bardzo powoli (błędnie określanymi mianem procesów reprodukcji społecznej), jak i też tymi, które postępują znacznie szybciej i gwałtowniej. Historia i przeszłość są ujmowane w antropologii szeroko, można powiedzieć globalnie. Procesy historyczne zachodzą wszędzie, a jednocześnie są ze sobą powiązane. Antropolodzy i antropolożki chętnie sięgają zarówno do uznanych przez historyków źródeł, jak też do historii mówionej, wizualnej, popularnej. Co więcej, antropologia wydaje się szczególnie uwrażliwiona na to, iż przeszłość podlega na bieżąco narratywizacji i że narracje historyczne wywierają ogromny wpływ na przebieg zdarzeń, a zatem również na przyszłość ludzkości. 


\section{W jakim stopniu możemy współcześnie mówić o dominujących stylach praktykowania antropologii; czy można by wskazać nurty i orientacje badawcze o charakterze paradygmatycznym?}

Można przeprowadzić przynajmniej kilka linii podziału, jeśli chodzi o praktykowanie antropologii. Po pierwsze, wciąż istotne są różnice regionalne. Oczywiście pojęcie regionów etnograficznych narażone jest na zasadną krytykę, jeśli przemyca ahistoryzm - wiarę w niezmienność kulturowych specyfik poszczególnych obszarów i zapoznaje wpływ zależności globalnych na formowanie się różnic i poczucia odrębności ze względu na miejsce. Równocześnie uprawianie antropologii wymaga bardzo dobrej, krytycznej, znajomości etnografii i historii danego obszaru świata. Dyskusje i spory w gronie specjalistów regionalnych pozostają owocnym źródłem wiedzy antropologicznej. Regionalizacja wpływa też na style myślenia samych antropologów/antropolożek z uwagi na odmienności sposobów uprawiania antropologii/etnologii w różnych częściach świata.

Po drugie, ważnym kryterium podziału są postępujące zróżnicowania między subdyscyplinami antropologii (a nawet sub-subdyscyplinami). Antropologia religii, antropologia ekonomiczna, antropologia medyczna czy antropologia językoznawcza są silnie wyodrębnionymi obszarami badań posiadającymi do pewnego stopnia swoiste pytania i problemy i specyficzne powiązania (w tym też napięcia) z innymi dziedzinami nauki (religioznawstwem, ekonomią, biomedycyną, psychologią kliniczną, lingwistyką).

Po trzecie, można mówić w antropologii o zróżnicowaniu praktyk poznawczych ze względu na założenia filozoficzne, przy czym zróżnicowania tego rodzaju czasami mają znaczenie drugorzędne i nie hamują wzajemnego przepływu idei; bywa jednak, że różnice są na tyle istotne, że prowadzą do trwalszych odmienności w praktykowaniu antropologii. Różnice takie występują np. między nurtami silnie anty-redukcjonistycznymi, czerpiącymi z poststrukturalizmu oraz równie mocno redukcjonistycznymi odwołującymi się do biologii ewolucyjnej. Mniej lub bardziej trwałe sploty praktyk poznawczych mogą odmiennie lub podobnie określać podstawowe cele antropologii i budować etos dyscypliny na dających się uzgodnić lub wzajemnie niekompatybilnych podstawach i zasadach.

Wątpię, by można było mówić w antropologii/etnologii o paradygmatach (pojęcie paradygmatu zbyt często jest kojarzone z ideą jakiejś zamkniętej pojęciowo i praktycznie całości), ale na pewno antropologowie/antropolożki różnią się między 
sobą w zakresie uprawiania krytyki wiedzy antropologicznej. Swoich zwolenników posiada idea błędu kardynalnego - mocne przeświadczenie, że cała dotychczasowa antropologia opiera się na jakimś zasadniczym błędzie. Sympatycy/sympatyczki idei błędu kardynalnego różnie zapatrują się na to, na czym w istocie ów błąd polega, ale tym, co ich łączy, jest dążenie do skierowania dyscypliny na nowe zupełnie tory. Chociaż wielokrotnie mówiło się i pisało o zasadniczych przełomach w myśleniu antropologicznym, to zerwania z przeszłością mają, jak sądzę, przeważnie charakter częściowy i nowe praktyki zachowują pewne przynajmniej cechy praktyk wcześniejszych.

\section{Jakie wyzwania stawia przed dyscypliną przyszłość?}

Wyzwanie główne i nieustające to dążenie do zrozumienia ludzkich sposobów życia w ich wielości i zmienności, podobieństwach oraz tym, co jest dla nich wspólne. Człowiek jest zwierzęciem, które samo siebie raz po raz zaskakuje, które poszukuje i błądzi, jednocześnie dążąc do samozrozumienia i porozumienia samo ze sobą i innymi gatunkami. Co za tym idzie, zadaniem antropologii jest ostrożne dążenie do wyjaśniania człowieka, pamiętające wszelako, że wszelkie wyjaśnienia naukowe są zawodne i ułomne, a przede wszystkim muszą pozostać otwarte na publiczną krytykę. Innym jeszcze wyzwaniem pozostaje wykazanie w debacie interdyscyplinarnej wagi badań terenowych i etnografii dla tworzenia teorii i metod w naukach społecznych. Zadaniem szczególnie ważnym jest również zaangażowanie w debatę publiczną, pozwalające aktywnie działać na wielu polach na rzecz przeciwdziałania samozniszczeniu gatunku ludzkiego. 


\section{Anna Malewska-Szałygin}

a.malewska-szalygin@uw.edu.pl

Instytut Etnologii i Antropologii Kulturowej

Uniwersytet Warszawski

Etnologia / antropologia kulturowa i społeczna jest to dyscyplina naukowa przez Ministerstwo (MNiSW) umieszczana w obszarze nauk humanistycznych, choć większość etnologów jest zdania, że dziedzina ta plasuje się pomiędzy obszarem humanistyki i nauk społecznych. Etnologia to nauka badająca współczesne procesy kulturowo-społeczne. Procesy te są dynamicznym połączeniem zmieniających się, różnorodnych dyskursów i praktyk realizowanych w relacjach bezpośrednich i zapośredniczonych przez technologie cyfrowe. Te dwa wymiary interakcji (bezpośredni i cyfrowy) są współcześnie nierozdzielne. Procesy, o których mowa, są badane poprzez obserwowanie i interpretowanie indywidualnych ludzkich doświadczeń.

W zależności od wybranego aspektu procesów kulturowo-społecznych możemy mówić o antropologii politycznej, ekonomicznej, mediów, antropologii religii i religijności, materialności, rzeczy, sztuki, antropologii wizualnej, antropologii etniczności, mobilności, migracji, miasta, globalizacji, antropologii cielesności, płci, medycyny, antropologii jedzenia i wielu innych. Et nologowie/a ntropologowie często angażują się w trudne problemy grup, które badają i aktywnie działają na rzecz poprawy ich sytuacji. Zwykle też podejmują działania na rzecz propagowania idei otwartości i tolerancji, przeciwdziałania dyskryminacji i mowie nienawiści. Et nog ra fia jest metodą prowadzenia badań wyróżniającą etnologię / antropologię kulturową spośród innych nauk humanistycznych i społecznych. Etnog raficzne badania terenowe, będące znakiem rozpoznawczym i „obrzędem przejścia plemienia antropologów" (James Clifford), polegają na długotrwałym przebywaniu $\mathrm{w}$ terenie łączącym obserwację uczestniczącą, wywiady otwarte, pogłębione oraz (ewentualnie) zalecane przez Kirsten Hastrup współdoświadczanie. Regułą jest wejście w relację 'zażyłości' (Ulf Herzfeld) z badaną grupą. W związku ze współczesną nierozdzielnością kontaktów bezpośrednich i zapośredniczonych cyfrowo do technik badawczych należy dołączyć obecność badacza realizowaną poprzez cyfrowe formy komunikacji (od telefonów komórkowych, smartfonów, przez Skype'a, fora i portale społecznościowe, po blogi, v-logi i inne). Ten wymóg znacznie rozszerza różnorodność materiałów źródłowych wytwarzanych w terenie (prócz transkrypcji 
i odbitek zdjęć, także pliki audio, video, pliki tekstowe, obrazy z aparatów cyfrowych, zrzuty z ekranu itd.).

Określenie teren, coraz częściej używane w cudzysłowie, może odnosić się do umiejscowień w przestrzeni realnej lub wirtualnej, a najczęściej dotyczy miejsc, w których realizowane są interakcje bezpośrednie i zapośredniczone cyfrowo. Materiały terenowe są analizowane i interpretowane za pomocą kategorii pojęciowych i założeń zaczerpniętych $\mathrm{z}$ wciąż zmieniających się teorii nauk humanistycznych i społecznych (koncepcja zwrotów!). W etnologii / antropologii kulturowej nie zawsze teoria, w ramach której zaplanowano projekt badawczy, okazuje się wystarczająca do interpretacji wszystkich wątków i aspektów pojawiających się w materiale źródłowym. Wówczas, podobnie jak w metodzie ugruntowanej, badacz może wykorzystywać narzędzia analityczne pochodzące $\mathrm{z}$ innych teorii. Kryterium naczelnym doboru zaplecza teoretycznego jest jego moc eksplanacyjna i adekwatność do źródeł wytworzonych w toku badań terenowych. Aktualnie widać wyraźnie zmierzch ujęć konstruktywistycznych skoncentrowanych na dyskursach, wyobrażeniach, konstruktach myślowych (takich jak np. wspólnoty wyobrażone Andersona) itp. Można obserwować zwiększone zainteresowanie praktykami, „ucieleśnieniem” i cielesnością, doświadczaniem, materialnością, a także teorią afektu, emocjami oraz antropologią zmysłów rejestrującą kulturowo-społeczny wymiar zapachów, dźwięków, odczuwania środowiska (wpływów atmosferycznych) itp.

Sytuację badania etnograficznego można opisać jako dialog (rozumiany szeroko jako wielogłos) pomiędzy kulturowo uwarunkowanymi partnerami, czyli badaczem (lub grupą badaczy) oraz jego rozmówcami, czyli grupą badaną. Relacja ta powinna być w jak największym stopniu partnerska, co w języku wyraża się zaleceniem unikania uprzedmiotawiających określeń, takich jak badani czy informatorzy. O tym, że osiągniecie rzeczywistego partnerstwa jest trudne, informuje lingwistyczna forma używanego słowa 'badacz' (wprowadzającego nieuchronnie okruch dominacji) oraz fakt, że finalnie to właśnie badacz referuje przebieg terenowego spotkania w formie raportów, referatów, artykułów i książek. Mimo że pełna realizacja postulatu partnerstwa nie jest możliwa, pozostaje ono ideałem relacji badawczej, do którego należy dążyć. Wiedza etnologiczna jest wytwarza $\mathrm{w}$ tak rozumianej sytuacji dialogu.

Przeszłość jest współcześnie wykorzystywana jako rodzaj rekwizytorni do tworzenia nowych konstruktów tożsamościowych. Elementy przeszłości, wyrwane 
z kontekstu i zestetyzowane (lub w inny sposób dostosowane do aktualnych wymogów) służą do wytwarzania wizerunków na potrzeby obecnego „supermarketu kultury" (Matthews). Wizerunki indywidualne, grupowe, regionalne, etniczne, narodowe prezentowane są w rzeczywistości doświadczanej bezpośrednio (muzea, skanseny, aranżacje kwater agroturystycznych [wnętrza, stroje, potrawy], konkursy, festiwale folklorystyczne, wydarzenia kulturalne, koncerty itp.) oraz zapośredniczonej cyfrowo (strony internetowe, profile, grupy i strony na Facebooku, Twitterze, fanpage'e, blogi, v-logi itp.)

\section{Robert Statkiewicz}

robertstatkiewicz@student.uw.edu.pl

\section{Co to jest etnografia/etnologia/antropologia (jej miejsce wśród innych dyscyplin, cele, metody)?}

Zdaję sobie sprawę, że etnografię, etnologię i antropologie często się ze sobą utożsamia. Wydaje mi się, że to pytanie jest interesującym punktem do zatrzymania się i próby dookreślenia każdego z terminów. Etnografia - jest przydatnym narzędziem metodologicznym opartym w dużej mierze na doświadczeniu i empirii. To skupienie się na praktyce, przebywaniu i wynoszeniu wiedzy z doświadczeń, rozmów i doznań. Etnologia - to nauka skupiająca się na ludziach i ich kulturze. Jej podstawowym narzędziem są metody etnograficzne. Antropologia - szeroko rozumiana nauka o człowieku. Na tym poziomie dochodzi do „licznych” (ale i niezwykle potrzebnych!) podziałów na kategorie, takie jak: antropologia ekonomiczna, antropologia seksualności itp. Należy wspomnieć, że wszystkie z tych nurtów zajmują się „kulturą" lub „kulturami”, jednak niektóre z nich wprowadzają również czynniki i terminologię zapożyczone z biologii, czyniąc pojmowanie kultury wielopłaszczyznowym. Bardzo często metody etnograficzne są w tych nurtach najistotniejszym narzędziem badawczym. Jak napisałem na początku, etnografię, etnologię i antropologię często się ze sobą utożsamia ze względu na wiele cech wspólnych tych dziedzin (przede wszystkim położenie nacisku na empirię). Najogólniej nauki te sytuowałbym na styku między naukami humanistycznymi, społecznymi i przy rodniczymi. 


\section{Jakie miejsce zajmuje w etnografii / etnologii / antropolo- gii kulturowej problematyka badań nad przeszłością?}

Nie jest to obszar, w którym czuję się kompetentnie. Aczkolwiek mam wrażenie, że $\mathrm{w}$ wielu pracach wątek przeszłości jest bardzo istotny i uwzględniany (zarysowuje kontekst). $Z$ drugiej jednak strony, dość dawno nie natknąłem się na interesujący artykuł próbujący niejako „zrekonstruować” przeszłość kulturową jakiejś społeczności.

\section{W jakim stopniu możemy współcześnie mówić o dominujących stylach praktykowania antropologii; czy można by wskazać nurty i orientacje badawcze o charakterze paradygmatycznym?}

Częstą praktyką jest współcześnie opieranie wiedzy teoretycznej wyłącznie o prace filozofów (np. Bruno Latour). Wydaje się, że brakuje reprezentacji teoretycznej tworzonej przez etnologów, antropologów i etnografów, nie mówiąc już o przedstawicielach innych nauk (archeologia i antropologia kognitywna).

\section{Jakie wyzwania stawia przed dyscypliną przyszłość?}

Mam wrażenie, że dla niektórych przedstawicieli dziedziny dużym problemem jest/będzie wzmożona interdyscy plinarność oraz transdyscyplinarność, która już teraz przez niektórych jest zbywana i określana „modnym słówkiem”. Oczywiście, wynika to z przeszłości naszej dziedziny, a raczej z tego, jak podchodziły (a czasem wciąż podchodzą) do niej pozostałe nauki, czyli bardzo często bagatelizująco. Jak usłyszałem na jednym z wykładów w Instytucie Filozofii: „co to jest etnologia albo jakaś tam antropologia kulturowa? To tylko psychologizujące kulturoznawstwo". Uważam jednak, że jako środowisko zajmujące się nienormatywnością, któremu nie obce jest pojęcie „relatywizmu”, nie powinniśmy obstawać przy „jedynej i słusznej” wizji dominującej antropologii, krytykując bardzo ostro metodologie pozostałych dziedzin. Innymi słowy - niektórzy z nas zachowują się dokładnie tak samo, jak osoby nierozumiejące i krytykujące nasze metody czy naukę w ogóle. 


\section{Ewa Tomaszewska}

etomaszewska@mwk.com.pl

Dział Etnografii

Muzeum Wsi Kieleckiej

Etnografia / etnologia / antropologia kulturowa to dyscyplina, która na gruncie polskim wyrosła z zainteresowania dziejami ludzkości, kulturą ludową, w której upatrywano nośnik tradycyjnych, rodzimych, narodowych wartości, a także fascynacji ludami pozaeuropejskimi i ich kulturą. Jej uwaga skierowana pierwotnie na „dzikich”, „lud”, zjawiska etniczne, z biegiem czasu przeniosła się również na współczesne zjawiska kulturowe, w tym tak zwaną kulturę popularną.

Etnografia to nauka empiryczna, a jej podstawowym wyróżnikiem jest metoda i specyficzne techniki badań terenowych, takie jak wywiad czy obserwacja uczestnicząca. Etnograficzne badania o charakterze jakościowym zwracają uwagę na szczegół i kulturowy kontekst, charakteryzują się podejściem badacza utrzymującego się w stanie ciągłego zdziwienia rzeczywistością i dostrzegania nieoczywistości w znanych zjawiskach. Etnografia zajmuje się obserwacją, całościowym opisem i analizą zjawisk kulturowych. Charakterystyczne dla etnografii są monografie określonych grup opisujące ich kulturę (grupy etnograficzne, plemienne, grupy środowiskowe, instytucje, subkultury). Etnografia może być rozumiana jako metoda etnologii czy antropologii kulturowej, początkowa faza - badania, opis i analiza mogą być wstępem do ogólnych rozważań, porównań, interpretacji i formułowania syntetycznych wniosków na temat człowieka i jego kultury rozumianej jako sposób życia.

Etnologia / antropologia kulturowa - nazwy najczęściej stosowane są wymiennie, różnice wynikają z historii dyscypliny, która w różnych krajach kształtowała się pod różnymi nazwami, a także ze względu na merytoryczny zakres badań. Etnologia rozumiana jest jako studia porównawcze między kulturami, nadbudowa nad opisową etnografią. Zwyczajowo odnosi się do badania kultur tradycyjnych, podczas gdy przedmiotem antropologii jest człowiek jako istota kulturowa, antropologia jest więc tu dyscypliną nadrzędną.

Etnologia / antropologia kulturowa, to nauka o człowieku i jego kulturze. Wyrosła ona z fascynacji „innością", początkowo głównie kulturą ludową/tradycyjną, społeczeństwami „pierwotnymi”. Powstała z chęci przekraczania kulturowych granic oraz spotkania z „obcością”. Pogłębiona refleksja nad odmiennością stawała się drogą do 
poznania samego siebie, do autorefleksji, spojrzenia z oddali na własną kulturę. Antropologia oznacza szczególny rodzaj podejścia do rzeczywistości kulturowej, które zakłada zdumienie tym, co wydaje się być bliskie, zwykłe, naturalne i uczynienia tego przedmiotem refleksji. Obecnie w kręgu zainteresowań etnologii jest całe spectrum zjawisk współczesnego życia, zwykle tych nieoczywistych, peryferyjnych. Etnologia bada świat idei i wyobrażeń, które kreuje człowiek i które rządzą jego życiem; dekonstruuje je, będąc pewnego rodzaju narracyjną opowieścią o kulturach.

Problematyka badawcza etnologii jest niezwykle różnorodna. Głównym obszarem zainteresowań jest kultura współczesna w różnych aspektach, uniwersalne ujęcie zjawisk kulturowych, problematyka związana z dyscypliną i jej samoświadomością, ale także, podobnie jak dawniej, badania nad przeszłością, swoiste rekonstrukcje, które szczególną rolę odgrywają w warunkach uprawiania etnologii w instytucji muzealnej typu skansenowskiego. Duże znaczenie mają tu studia społeczności regionalnych z szerokimi odwołaniami do kultury tradycyjnej, które postrzegane są jako istotne dla współczesnego regionalnego życia kulturalnego i lokalnej tożsamości.

Etnologiczne podejście i metody mają znaczenie społeczne, mogą być wykorzystywane w dokumentacji i prezentacji tradycji kultur lokalnych czy regionalnych, a także w zrozumieniu odrębności kulturowych.

Ze względu na rozległy zakres antropologii, szczególne podejście łączące doświadczenie empiryczne z teorią, ma ona wśród nauk humanistycznych wyjątkowy status. Podejście antropologiczne służy wielu naukom społecznym i humanistycznym, wykorzystywane jest w socjologii, historii, archeologii, filozofii, kulturoznawstwie czy językoznawstwie. Może mieć również zastosowanie w zarządzaniu, gospodarce i innych dziedzinach.

Etnologia, podobnie jak sama kultura, nie jest jednorodna, charakteryzuje się wielością podejść i metodologii, dopuszcza interdyscyplinarność, która w dzisiejszej nauce wydaje się nieodzowna. Antropologia kulturowa to nauka samorefleksyjna, której paradygmat bywa redefiniowany. Dostrzega ona uwarunkowania związane z własnymi ograniczeniami, z subiektywnością poznania, uwzględnia znaczenie jego pozalogicznych elementów, które mają wpływ na rozumienie danego problemu, dopuszcza ambiwalencję i paradoks. Podkreśla dialogiczność czy wielogłosowość swojego podejścia, które odpowiada polifoniczności kultury w ogóle.

Ze względu na wielość kulturowych przestrzeni, które wymagają często różnych metod i sposobów opisu, antropologia kulturowa wykształca określone specjalizacje, 
opisujące ów „świat w kawałkach”, takie jak: antropologia rzeczy, miasta, obrazu, pamięci, itd. Zmieniająca się w szybkim tempie rzeczywistość (nowe technologie, style życia, mody, nowoplemiona, migracje, sposoby uży tkowania zasobów kulturowych itd.) ciągle stawia przed etnologią nowe wyzwania i nieograniczone możliwości; zakres jej badań wciąż się poszerza, gdyż kultura to czynny proces. Etnograficzny opis, analiza i antropologiczny namysł nad różnorodnymi zjawiskami kulturowymi są niezwykle istotne. Etnolog musi wykazywać się uważnością, otwartością i wrażliwością, aby dostrzec szczegóły i niuanse, które wprawnego obserwatora doprowadzą do trafnej interpretacji i wyjaśnienia prowadzącego do zrozumienia ich istoty, a czasem również zmiany własnego oglądu świata.

\section{Tomasz Wojczak}

wojczaktomasz@wp.pl

\section{Co to jest etnografia/etnologia/antropologia (jej miejsce wśród innych dyscyplin, cele, metody)?}

W dniu 15 III 2016 r. Rada Wydziału Historycznego Uniwersytetu im. Adama Mickiewicza w Poznaniu nadała mi tytuł doktora nauk humanistycznych w dyscyplinie zwanej etnologią, tudzież antropologią kulturową. Wydarzenie to powoduje, że nie mogę mej odpowiedzi w ankiecie pisać jako osoba z zewnątrz dyscypliny - znajduję się bowiem wewnątrz niej, choć na jej marginalizowanych obrzeżach. Jednakże czuję się przede wszystkim - zgodnie z moim wykształceniem uzyskanym w wyniku studiów magisterskich - historykiem i filologiem. Piszę o tym, ponieważ odpowiedzi, jakie padną za chwilę na zadane w ankiecie pytania, wynikają bezpośrednio z mojej przedstawionej w skrócie biografii naukowej. Dodam jeszcze, że moja praca doktorska dotyczyła związków między kulturą ludową a teatrem na podstawie Dialogu Mistrza Polikarpa ze Śmiercią i Skargi umierającego. Obecnie zajmuję się sposobami posługiwania się gestem w sztuce polskiego średniowiecza oraz testamentami chłopów polskich z XVII-XVIII wieku. Mogę o sobie powiedzieć, że jestem antropologiem z przypadku - jednakże uwielbiam antropologię i dobro tej dyscypliny naprawdę leży mi na sercu. 
Na podstawie przeczytanych podręczników i licznych książek antropologicznych stwierdzam, że jedyną definicją antropologii i antropologii kulturowej, pod którą bym się podpisał, są słowa Tima Ingolda, który napisał, że: „Antropologia to filozofia $\mathrm{z}$ ludźmi w środku". Jestem osobą, która kontakt $\mathrm{z}$ literaturą antropologiczną rozpoczęła dzięki lekturze tekstu Jacquesa Le Goffa i Pierre’a Vidal-Naqueta zatytułowanego Lévi-Strauss w Broceliandzie przedrukowanego w książce pierwszego z wymienionych autorów zatytułowanej Świat średniowiecznej wyobraźni. Dwie pierwsze książki antropologiczne przeczytane przeze mnie to dwa tomy Antropologii strukturalnej Claude'a Lévi-Straussa. Etnologia w tradycji francuskiej była pojmowana jako synonim antropologii kulturowej i tak też ją rozumiem. Nie czuję bowiem między nimi różnicy. Natomiast etnografia to dla mnie synonim opisu gęstego.

Pojęcie 'opisu gęstego', jak powszechnie wiadomo, wprowadził do antropologii Clifford Geertz, który obok Victora Turnera, Sherry B. Ortner i Mary Douglas jest dla mnie jednym z najwybitniejszych etnologów. Przedmiotem antropologii jest według mnie, człowiek we wszystkich swoich przejawach, co jak wiadomo, koresponduje z definicją historii Luciena Febvre'a i powoduje, że obie te dyscypliny idą ramię w ramię.

Miejsce jakie zajmuje antropologia wśród innych nauk o człowieku? Na to pytanie odpowiedź może być tylko jedna. Antropologia kulturowa to królowa nauk humanistycznych i społecznych. Jest to swoista płaszczyzna, na której może dojść do realizacji marzenia L. Febvre’a i Marca Blocha, by stworzyć jedną ogólną naukę o człowieku, integrującą humanistykę i nauki społeczne. Dla Febvre’a i Blocha nauką tą była historia, dla mnie stała się nią antropologia kulturowa. C. Geertz porównał kiedyś historię do słonia, a antropologię do królika. Pod względem roli jaką, niestety, pełnią w kulturze obie nauki, oba porównania są słuszne. Jednakże biorąc po uwagę role, jakie w metodologii nauk odgrywają te dyscypliny, można powiedzieć, że to antropologia jest słoniem, a historia królikiem. Dlatego nie sposób dziś nowocześnie uprawiać humanistyki bez posiadania wiedzy antropologicznej.

Wyróżniłbym trzy cele, jakie stoją przed antropologią kulturową na świecie i w Polsce. O pierwszym już pisałem - integracja nauk społecznych i humanistycznych. Pozostałe dwa to przekształcenie studiów etnologicznych w studia zawodowe (można bowiem utworzyć na etnologii co najmniej dwie specjalizacje - muzealnictwo i antropologię organizacji) i wejście antropologii do szkół powszechnych - mam na myśli licea. 
Metody etnologii? Obserwacja uczestnicząca pozostaje metodą najważniejszą, od której etnologia nie może odejść. Jednakże ten typ obserwacji nie może być pojmowany jako wyróżnik antropologii - jej specyfiką powinno być traktowanie badanej kultury jako Innej i pokazywanie podobieństw oraz różnic pomiędzy naszą kulturą, a kulturą ludzi badanych.

\section{Jakie miejsce zajmuje w etnografii / etnologii / antropolo- gii kulturowej problematyka badań nad przeszłością?}

Miejsce zajmowane przez badanie przeszłości, czyli historii w polskiej antropologii kulturowej jest stanowczo zbyt małe. Nieszczęsna rola odgrywana przez obserwację uczestniczącą w dydaktyce uniwersyteckiej, brak zajęć z nauk pomocniczych historii oraz brak fakultetu z łaciny długo tego nie zmienią.

\section{W jakim stopniu możemy współcześnie mówić o dominujących stylach praktykowania antropologii; czy można by wskazać nurty i orientacje badawcze o charakterze paradygmatycznym?}

Wydaje mi się, że nie ma obecnie dominującego paradygmatu w antropologii. Zapanował pluralizm metodologiczny i jest to zjawisko waloryzowane przeze mnie jak najbardziej pozytywnie.

\section{Jakie wyzwania stawia przed dyscypliną przyszłość?}

Powtórzę to, co pisałem o celach. Wejście antropologii do liceów i przekształcenie studiów etnologicznych w zawodowe oraz integracja nauk społecznych i humanistycznych. 


\section{Karolina Zuba}

zubov@o2.pl

Muzeum Budownictwa Ludowego w Sanoku

\section{Co to jest etnografia/etnologia/antropologia (jej miej- sce wśród innych dyscyplin, cele, metody)?}

Pytanie o miejsce etnografii, etnologii i antropologii kulturowej we współczesnej humanistyce, czy też o relacje, jakie zachodzą pomiędzy tymi dyscyplinami, jest pytaniem akademickim, stawianym częściej w rozważaniach teoretycznych niż praktycznych. Z perspektywy pracy muzealnika, szczególnie w muzeum etnograficznym, a takim jest Muzeum Budownictwa Ludowego w Sanoku, wszystkie te dziedziny są niezmiernie istotne, przede wszystkim ze względu na wypracowane specyficzne techniki badawcze, które znajdują zastosowanie w pracach naukowych muzeum. W Muzeum Budownictwa Ludowego etnografia, etnologia czy antropologia wykorzystywane są nieustannie. Z jednej strony, traktowane są one jako pewna perspektywa badawcza, specyficzny sposób widzenia całego świata i konkretnych faktów kulturowych, z drugiej, stosowane są charakterystyczne dla tych dyscyplin techniki badawcze.

Wszystkie działania Muzeum Budownictwa Ludowego dotyczą kultury. Pracownicy MBL zajmują się zarówno jej wymiarem materialnym, jak i duchowym. Dlatego też etnografia, etnologia, antropologia kultury z ich metodami i technikami badawczymi są wyjątkowo ważnymi dziedzinami humanistyki, które pozwalają nie tylko prowadzić badania, ale też analizować zgromadzony w Muzeum materiał badawczy. W ramach takich działań prowadzone są badania terenowe: wywiady, obserwacje, dokumentacja i opracowanie naukowe tychże i wreszcie publikacje. Zasadniczą częścią działań Muzeum jest jednak gromadzenie zbiorów, które są opracowywane naukowo, poddawane konserwacji i wreszcie udostępniane zwiedzającym. MBL, zajmując się raczej praktyką niż teorią i metanauką, nie powinno zajmować jasnego stanowiska w kwestii relacji pomiędzy ww. dziedzinami i ich miejscem we współczesnej humanistyce, nie jest to bowiem bezpośrednim przedmiotem jego działań. 


\section{Jakie miejsce zajmuje w etnografii / etnologii / antropolo- gii kulturowej problematyka badań nad przeszłością?}

Specyfika muzeum sprawia, że badania nad przeszłością zajmują bardzo ważne, jeśli nie kluczowe miejsce we wszelkich jego działaniach. Etnograficzne techniki badawcze (wywiady, obserwacje) oraz gromadzenie i naukowe opracowywanie zbiorów etnograficznych pozwalają w znacznym stopniu rekonstruować zanikające już elementy dawnej kultury ludowej, miejskiej czy też szlacheckiej (dotyczy to zarówno kultury materialnej, jak i sfery duchowej oraz społecznej). Prowadzone przez pracowników MBL badania pomagają umiejscowić eksponaty w odpowiednim kontekście kulturowym i historycznym, co pozwala na odpowiednie tworzenie ekspozycji. Dzięki temu zwiedzający mają okazję zapoznać się nie tylko z historią regionu, ale i jego dawną kulturą.

Oczywiście nie jest to jedyny sposób uprawiania przez pracowników Muzeum etnografii. Kolejne ważne działania to dokumentacja otaczającej rzeczywistości (która przecież kiedyś stanie się przeszłością). Tutaj także sprawdza się niezawodnie klasyczny warsztat etnografa/etnologa - wywiady, obserwacje (w tym uczestniczące) i, co oczywiste, dokumentacja prowadzonych działań, w czym znakomicie pomaga współczesna technologia.

\section{W jakim stopniu możemy współcześnie mówić o dominujących stylach praktykowania antropologii; czy można by wskazać nurty i orientacje badawcze o charakterze paradygmatycznym?}

Powyżej opisano w jaki sposób etnografię i antropologię praktykuje się w MBL. Czy jest to styl unikalny, czy raczej metoda powszechna pomogą ustalić przeprowadzone już przez Państwa analizy komparatystyczne otrzymanych odpowiedzi.

\section{Jakie wyzwania stawia przed dyscypliną przyszłość?}

Cele etnografii, etnologii, antropologii to nie tylko gromadzenie danych o otaczającej nas rzeczywistości, ale również ich analiza (także porównawcza), próba zrozumienia, wyciągania wniosków czy wreszcie prognozowania. Kultura wciąż się zmienia, nieustannym przekształceniom ulegają poszczególne jej aspekty, elementy, fragmenty, 
nie powinno więc zabraknąć pracy zarówno dla gromadzących materiały badawcze przy pomocy klasycznych metod etnografii, jak i dla analizujących, porównujących, podsumowujących i wyciągających wnioski antropologów. 
